NBER WORKING PAPER SERIES

\title{
DO RACE AND FAIRNESS MATTER IN GENEROSITY? EVIDENCE FROM A NATIONALLY REPRESENTATIVE CHARITY EXPERIMENT
}

\author{
Christina M. Fong \\ Erzo F.P. Luttmer \\ Working Paper 15064 \\ http://www.nber.org/papers/w15064
NATIONAL BUREAU OF ECONOMIC RESEARCH
1050 Massachusetts Avenue
Cambridge, MA 02138
June 2009

Funding by NSF (grant \# 0555004 and 0555049), TESS, and Knowledge Networks is gratefully acknowledged. Erzo Luttmer also gratefully acknowledges funding from the National Institute on Aging through Grant Number T32-AG00186 to the National Bureau of Economic Research. Andra Hibbert and Kate Mikels provided excellent research assistance, Jami Gates and two charities in Tuscaloosa, AL, assisted in photographing the city and local charity recipients, and Jennifer Shultis kindly agreed to do the voice-over for the slide show. We are grateful to participants of the Middlebury workshop on the Current State of Philanthropy for helpful comments. All errors are our own. The views expressed herein are those of the author(s) and do not necessarily reflect the views of the National Bureau of Economic Research.

NBER working papers are circulated for discussion and comment purposes. They have not been peerreviewed or been subject to the review by the NBER Board of Directors that accompanies official NBER publications.

(C) 2009 by Christina M. Fong and Erzo F.P. Luttmer. All rights reserved. Short sections of text, not to exceed two paragraphs, may be quoted without explicit permission provided that full credit, including (C) notice, is given to the source. 
Do Race and Fairness Matter in Generosity? Evidence from a Nationally Representative Charity Experiment

Christina M. Fong and Erzo F.P. Luttmer

NBER Working Paper No. 15064

June 2009

JEL No. C93,D63,D64,H41,J71

\begin{abstract}
We present a dictator game experiment where the recipients are local charities that serve the poor. Donors consist of approximately 1000 participants from a nationally representative respondent panel that is maintained by a private survey research firm, Knowledge Networks. We randomly manipulate the perceived race and worthiness of the charity recipients by showing respondents an audiovisual presentation about the recipients. The experiment yields three main findings. First, we find significant racial bias in perceptions of worthiness: respondents rate recipients of their own racial group as more worthy. Second, respondents give significantly more when the recipients are described as more worthy. These findings may lead one to expect that respondents would also give more generously when shown pictures of recipients belonging to their own racial group. However, our third result shows that this is not the case; despite our successfully manipulating perceptions of race, giving does not respond significantly to recipient race. Thus, while our respondents do seem to rate ingroup members as more worthy, they appear to overcome this bias when it comes to giving.
\end{abstract}

Christina M. Fong

Department of Social and Decision Sciences

Carnegie Mellon University

500 Forbes Avenue, BP 208

Pittsburgh, PA 15213

fong2@andrew.cmu.edu

Erzo F.P. Luttmer

Kennedy School of Government, Mailbox 25

Harvard University

79 John F. Kennedy Street

Cambridge, MA 02138

and NBER

erzo_luttmer@harvard.edu 


\section{Introduction}

There is now broad agreement among social scientists that race and fairness are two of the most important determinants of generosity to the poor. ${ }^{1}$ Empirical evidence from many different levels of analysis points to significant, and often substantial, effects of racial and ethnic group loyalty on redistribution. Across countries, those with more racial or ethnic fractionalization have less governmental redistribution (Alesina, Glaeser and Sacerdote 2001). Across states within the United States, those with more ethnic fractionalization spend less on public goods and social services (Alesina, Baqir and Easterly 1999). Across individuals, those who live in a locality with a higher fraction of welfare recipients of a different race are significantly more opposed to redistribution (Luttmer 2001), and racial attitudes seem to play an important role in attitudes to redistribution (Gilens 1999, Lee and Roemer 2006). ${ }^{2}$

The role of fairness in redistribution has also received a great deal of research attention. By fairness we mean strong reciprocity, which is the propensity to incur pecuniary costs to reward those who have been kind and to punish those who have been unkind (Gintis 2000, Fehr, Fischbacher, and Gächter 2002, Bowles and Gintis 2004). The type of "kindness" that motivates reciprocation involves good intentions, regardless of the outcome of those intentions (Rabin 1993). The strong reciprocity motive can be generalized such that people may want to reward those who have helped others or society in general and to punish those who have hurt others or society in general. Thus, strong reciprocity may motivate people to reward the industrious poor for trying hard to make it on their own by giving more charity or supporting more governmental redistribution to the poor; and to punish the "lazy" poor by withholding charity or opposing governmental redistribution to the poor (Fong, Bowles and Gintis 2006). ${ }^{3}$

\footnotetext{
${ }^{1}$ See Alesina and Giuliano (2009) for a review.

${ }^{2}$ For recent theoretical work, see Shayo (2009) and Lindqvist and Östling (2009) for interesting models of social identity (including racial identity) and redistribution.

${ }^{3}$ Evidence that people are more generous to the industrious poor than to the "lazy" poor can also be explained by related concepts from other fields, including: i) the equity principle of distributive justice, according to which the resources one receives from a system should increase with one's inputs into the system (Walster, Walster and Berscheid 1978, Deutsch 1985); and ii) attribution theory in social psychology, according to which people are less generous to people whom they judge to be individually responsible for their need (Weiner 1995). See Konow (2003) for a review of empirical evidence on distributive justice.
} 
Economists have modeled the relationships between beliefs about the causes of income, individual economic experiences, and governmental redistribution (Piketty 1995, Alesina and Angeletos 2005, Bénabou and Tirole 2006). These models show that it is possible to have multiple stable equilibria: an equilibrium in which levels of redistribution are low and people tend to believe that income is largely caused by effort, or an equilibrium in which levels of redistribution are high and people tend to believe that income is caused by circumstances beyond their control. There is also empirical evidence of a strong association between opposition to redistribution and beliefs that the poor are lazy rather than industrious. ${ }^{4}$ This relationship emerges at both the cross-country level and the individual level within countries (Alesina, Glaeser and Sacerdote 2001, Corneo and Grüner 2002); moreover, at the individual level, the relationship cannot be explained by missing measures of socioeconomic status (Fong 2001). In laboratory experiments using real payoffs, respondents give more to recipients who might be interpreted as having greater moral worth (Hoffman, McCabe, Shachat, and Smith 1994, Eckel and Grossman 1996, Fong 2007, Durante and Putterman, 2008). Similarly, randomized survey experiments show substantially more support for government spending on "caring for the poor" or on "helping the poor" than on "welfare." Political scientists have argued that this result supports the claim that people tend to judge welfare recipients as a particularly unworthy social category (Heclo 1986, Gilens 1999).

For neither race nor fairness, however, is the supporting evidence based on studies that simultaneously use (i) real monetary transfers to the poor, (ii) randomized treatments of race and fairness, (iii) a nationally representative sample, and (iv) decision-making in a natural environment. We know of no evidence that is based on all four desiderata. In this paper, we present the results from, to the best of our knowledge, the first study to produce data based on the first three desiderata: behavioral measures of redistribution to the poor, random treatments of race and worthiness, and national representativeness. We see our paper as complementary evidence to field experiments, which typically meet all desiderata except the third (Frey and Meier 2004, Croson and Shang 2005, Landry et al. 2006, Falk 2007, Karlan and List 2007, Eckel and Grossman 2008, DellaVigna, List, and Malmendier 2009, List and Price 2009, Meer 2009).

\footnotetext{
${ }^{4}$ See Williamson (1974) for an early example of such a finding.
} 
Our experiment is a dictator game in which the recipients are local charities that serve the poor in the city of Tuscaloosa, Alabama. Donors consist of approximately 1,000 participants from a nationally representative respondent panel that is maintained by a private survey research firm, Knowledge Networks. We randomly manipulate the perceived race and worthiness of the charity recipients by showing respondents an audiovisual presentation about the recipients. Our "black" treatment shows photos mostly of black charity recipients while our "white" treatment shows photos mostly of white charity recipients. The photos are presented along with an audio story in which we manipulate perceptions of the worthiness of the charity recipients. We find that our treatments are successful - they have significant direct effects in the expected direction on perceptions of the race and worthiness of the recipients. We then give each respondent a ten percent chance of receiving $\$ 100$. Prior to learning whether or not they will receive the $\$ 100$, respondents must decide how much of that sum they would like to donate to the assigned charity in the event that they receive it. Finally, we collect survey data on a variety of attitudes and beliefs, including perceptions of the worthiness and race of the recipients. These perception measures are designed to test whether our treatments successfully manipulated beliefs about the recipients.

Our experiment generates three main results. First, we find significant racial bias in perceptions of worthiness: respondents rate recipients of their own racial group as more worthy, and rate more worthy recipients as more likely to belong to their own racial group. Second, respondents give significantly more generously when the recipients are described as more worthy. In particular, audio treatments that raise the perceived fraction of worthy recipients by 15.2 percentage points cause the respondents to increase their giving by $\$ 11.0$. This result, together with our finding of racial bias in perceptions of worthiness, may lead one to expect that respondents would also give more generously when shown pictures of recipients belonging to their own racial group. However, as our third result demonstrates, this is not the case; despite our successfully manipulating perceptions of race, respondents give about the same amount irrespective of the race of the recipients in the pictures. For instance, the non-black respondents give $\$ 61.0$ on average when white recipients are shown and $\$ 58.9$ on average when black recipients are shown. The difference of $-\$ 2.1$ is not statistically significant $($ s.e. $=2.7)$ and relatively 
small compared to the mean level of giving. Thus, while our respondents do rate ingroup members as more worthy, they appear to overcome this bias when it comes to giving.

In the remainder of the paper, Section 2 presents our experimental design, Section 3 presents our results, and Section 4 concludes with our interpretation of our results. As we will explain in the conclusion, we do not believe that our failure to find racial bias in giving contradicts prior evidence of discrimination and racial group loyalty. First, racism may have been higher in the past. Second, there may be racial discrimination in the real world that our study fails to detect. Finally, even if there currently is no racial bias in individual preferences for redistribution, cumulative effects of prior discrimination may cause racial inequalities to persist.

\section{Experimental Design}

Our experiment was fielded by Knowledge Networks, a market research firm founded by two Stanford political science professors. Knowledge Networks maintains a roughly nationally representative panel of respondents for use in both commercial and academic projects. Its respondents participate in surveys approximately once a week by Internet or Web TV. In exchange for their participation, Knowledge Networks panelists receive free Internet or WebTV access and receive the monetary incentives from some surveys. For example, our respondents received whatever monetary payoffs they earned from our experiment. Panelists are recruited through random-digit dialing and are then asked to join the Knowledge Networks panel.

In our experiment, we manipulate respondents' perceptions of the poor. More specifically, we focus on perceptions of race and "worthiness" of recipients of two local charities in Tuscaloosa, Alabama. We accomplish this with a slide show that presents eight photographs along with two and a half minutes of audio. The slide show describes the city of Tuscaloosa, one of two randomly-assigned charities, and recipients of aid from that charity. Half of our respondents saw a slide show depicting the work of the Salvation Army in Tuscaloosa, and the other half saw a slide show depicting the work of Temporary Emergency Services in Tuscaloosa. 
We took care to manipulate race perceptions in a way that minimized the likelihood that respondents would recognize the racial motivation of our study. Thus, we did not mention the issue of race in the audio part of our slide show. Instead, we manipulated perceptions of recipient race with the photographs. Half of our respondents saw photos mostly of black charity recipients, and the other half saw photos mostly of white charity recipients. ${ }^{5}$ We made the backgrounds of the photos of blacks and whites as similar as possible (nearly identical in most cases) by taking the photos of blacks and whites in exactly the same location.

The audio portion of our slide show is designed to manipulate perceptions of recipient worthiness and other characteristics. We avoid using deception by including different pieces of true information in different treatment conditions. For example, in our manipulation of the economic standing of Tuscaloosa, one treatment condition correctly states that the poverty rate in Tuscaloosa "is almost twice as high as the rest of the country," and the other treatment condition correctly states that Tuscaloosa's "per capita income ... is more than $5 \%$ higher than the rest of the state." Below we summarize our randomly assigned audio manipulations. The issues being manipulated are in bold text (with the fraction of participants assigned to each condition of the manipulation in parentheses). The treatment conditions for each manipulation are listed together with the values ( 0 or 1$)$ we give them when they are used as dummy variables. With one exception, each randomized manipulation contains two conditions. The exception is the reasons for poverty and willingness to work manipulation, in which there are three conditions. ${ }^{6}$ For each manipulation, each respondent was assigned to one and only one treatment condition. The exact wording of the audio conditions is provided in Appendix A.

\footnotetext{
${ }^{5}$ We did not show pictures exclusively of one race because that might arouse suspicions among the respondents. Instead, in the black treatment condition, approximately $80 \%$ of the pictures are of blacks while in the white treatment condition approximately $80 \%$ of the pictures are of whites.

${ }^{6}$ In the reasons for poverty and willingness to work manipulation, we assigned $50 \%$ to the default condition in which we said nothing about the work ethic of the poor and said that the reasons for poverty are a mixture of factors including bad choices and circumstances beyond control. Among the other $50 \%$ of subjects, half were assigned to the Reason for poverty bad choices, not willing to work condition and half were assigned to the Reason for poverty beyond control, willing to work condition. The actual number of observations in each condition differs slightly from $50 \%$ or $25 \%$ because of non-response (see Section 3 for details about excluded participants). The actual fraction of participants in each treatment condition is presented in Table 1.
} 
i) City is Republican (50/50):

0 . "Compared to the rest of Alabama, more people in Tuscaloosa vote for the Democratic Party"

1. "Like the rest of Alabama, people in Tuscaloosa vote overwhelmingly for the Republican Party"

ii) City is economically advantaged (50/50):

0 . "...with a poverty rate that is twice as high as in the rest of the country"

1 . "...with a per capita income that is more than $5 \%$ higher than the rest of the state"

iii) Reason for poverty and willingness to work (50/25/25): Many of the poor in Tuscaloosa are poor because of

0 . "...a mixture of factors including bad choices... and bad luck" and work ethic not mentioned

1. "bad choices" and "many of them wish they could rely on more generous assistance"

1. "circumstances beyond their control" and "many of them try to get a job..."

iv) Religious (50/50):

0 . [Nothing said]

1. Many of the poor in Tuscaloosa "pray to God regularly to ask Him for help"

v) Salvation Army (50/50): The charity depicted is

0 . Temporary Emergency Services

1. Salvation Army

vi) Short-term need for aid (50/50): Many of the charity's recipients use its help

0 . "...for long periods of time"

1. "...for short periods of time when it is absolutely necessary"

vii) Currently working (50/50): the charity is busy "before people receive their next"

0 . "government benefits check"

1. "paycheck"

viii) Sharing own aid with others (50/50): "Many recipients are"

0 . "competitive about getting aid"

1. "willing to share their allotment with others in need"

ix) Law-abiding (50/50): It is often hard for recipients to get well-paying jobs because "many employers are reluctant to hire"

0 . "people who have a criminal record"

1. "them"

Immediately following the slide show, we measure generosity to the poor in

Tuscaloosa with actual giving to the charity depicted in the slide show. We explain that we will give $\$ 100$ to one out of every ten participants in this study and ask respondents to decide how much of that money they would like to give to the Tuscaloosa charity. ${ }^{7}$ That is, respondents had a 10\% chance of playing a $\$ 100$ dictator game with the Tuscaloosa charity.

After respondents enter their dictator game decision, we ask a series of questions designed to check the effectiveness of our treatments. These questions measure perceptions of the charity recipients and all the residents of Tuscaloosa. For each

\footnotetext{
${ }^{7}$ To credibly convey that each respondent had a 10 percent chance of being selected, we assigned each respondent a number between 0 and 9 , and told him that his decision will be carried out if his assigned number is equal to the first number of the Louisiana State Pick3 lottery on a specified future date. Moreover, we told the respondent that the charity would send him a note specifying the amount of his donation. This was subsequently carried out as promised.
} 
treatment condition, there is a perceptions question designed specifically to test its effectiveness. Finally, we conduct a survey of background characteristics and attitudes. This survey includes a variety of questions, including past charitable giving, attitudinal support for government transfers to the poor in Tuscaloosa, attitudinal support for charitable transfers to the poor in Tuscaloosa, preferences for government spending in general, beliefs about causes of poverty, perceptions of racial composition of charity recipients, social contact with people of other races, and attitudes about racial inequality of opportunity.

\section{Results}

The experiment was fielded in 2006 from August 28 to September 20. A total of 1167 respondents participated. We limit our sample to the 989 individuals who indicated that they could clearly hear the speaker in our audio presentation. An additional seven respondents did not answer the question about how much they would like to give during the experiment, so we also dropped these observations. Our final sample consists of 982 respondents, of which 204 are black. Since we oversampled black respondents, we weight all of our results to correct for this oversampling. Appendix Table 1 compares the means and standard deviations of demographic variables in our Knowledge Networks data to those in the June 2006 Current Population Survey. The demographic means are roughly similar in magnitude even though there are significant differences in age, education, income, household structure, and marital status. There are no significant differences in the means of race, region, and work status dummies (except for a marginally significant difference in the fraction of respondents who are disabled).

Table 1 presents summary statistics for the full weighted sample. The average donation was $\$ 58.7$ (s.d. $=\$ 37.2$ ), and roughly $11 \%$ of the respondents gave zero. About $21 \%$ of the sample gave the median donation of $\$ 50$, and about thirty-six percent of the respondents gave the full $\$ 100$. The total payout from the experiment to the charities was $\$ 5995$. Figure 1 presents the cumulative density function of giving during the experiment for the full weighted sample. Slightly more than $20 \%$ gave between zero and $\$ 50$, and approximately $10 \%$ of the respondents gave between $\$ 50$ and $\$ 100$. 
This fairly high level of giving in this experiment is not too surprising. In standard laboratory dictator games, in which students give anonymously to other students, average donations are around $10 \%-15 \%$ of the total (Camerer 2003). However, studies have shown that average offers in dictator games vary greatly due to a variety of factors. Factors that may have increased average giving in our experiment include social proximity, which can be increased by providing information about recipients (Bohnet and Frey 1999); ${ }^{8}$ the perceived level of need of the recipients (Fong and Luttmer 2009); and our lottery method of assigning endowments to respondents, which may have decreased their sense of entitlement to the sum (Hoffman, McCabe, Shachat, and Smith 1994). Since so many factors can affect the overall level of giving in dictator games, our interest lies exclusively in the marginal effects of our treatment conditions and background variables. We use the dictator game simply as a tool to obtain a measure of generosity towards the poor that is based on an actual, payoff-relevant choice. We therefore do not interpret average giving in this experiment as an estimate of the marginal propensity to give.

\subsection{Treatment effects on perceptions of charity recipients}

Tables $2 \mathrm{a}$ and $2 \mathrm{~b}$ present the effects of our treatments on corresponding perceptions of the charity recipients and Tuscaloosa residents using the whole sample. This table shows that, by and large, our treatments successfully manipulated the perceptions they were designed to affect. Each column presents a regression where the outcome variable is one of the perception measures. The rows show the effects of our treatments on each of these perceptions.

Row (a) shows the effect of presenting photos of black charity recipients. We expected the black photos to have positive effects in columns 1 and 10. The outcome variable in these columns is the perceived percentage of people who are black minus perceived percentage who are white, where the people in question are aid recipients (column 1) and Tuscaloosa residents (column 10). As depicted in column 1, black photos increase the perceived fraction of charity recipients who are black-minus-white by 21.8

\footnotetext{
${ }^{8}$ See also Small and Loewenstein (2003) for related work on the "identifiable victim effect."
} 
percentage points. This effect is significant at the one-percent level and establishes that our treatments successfully manipulated perceptions of recipient race. In column 10, the effect of black photos on the perceived fraction of Tuscaloosa residents who are blackminus-white is 15.3 percentage points and is also significant at the one-percent level.

Row (a) also shows that black photos have highly significant negative effects on perceptions about the worthiness of the charity recipients. Columns 2 through 4 present regressions where the outcome variables are perceptions of worthiness. These columns show that the black photos have highly significant negative effects on beliefs that the recipients were: (2a) "willing to work hard in order to get ahead in life", (2b) "poor mainly because of reasons beyond their control", and (2c) not "poor mainly because of bad choices in their personal lives." Column 3 shows that the black photos had a highly significant negative effect on beliefs that the recipients have no criminal record, while column 4 shows that black photos had a negative, but insignificant, effect on perceptions that recipients are willing to share their aid with others. As we will show in Table 3 below, the negative effect of black photos on perceived recipient worthiness is driven entirely by the non-blacks in our sample; among blacks, the effect of black photos on perceived recipient worthiness is small and insignificant. Hence, these results offer a first indication of our finding of racial bias in perceptions of worthiness.

Rows (b) and (c) show the effects of the first two worthiness treatments. Row (b) shows the effects of describing recipients as poor for reasons beyond their control and being willing to work. Row (c) presents the effects of describing recipients as being poor because of bad choices and not very interested in working hard. The omitted control treatment for rows (b) and (c) described recipients as poor because of a mixture of bad choices and circumstances beyond control and did not mention work ethic. The treatment presented in row (b) occurred in $25 \%$ of the cases, the treatment presented in row (c) occurred in another $25 \%$ of the cases, and the omitted control condition occurred in the remaining $50 \%$ of the cases. The worthiness perceptions that are the dependent variables in columns $2 \mathrm{a}$ through $2 \mathrm{c}$ were designed specifically to test the effectiveness of these two worthiness treatments. We expect the treatment in row (b) to have positive effects in

\footnotetext{
${ }^{9}$ The outcome in columns (2c) and (3) are reverse coded from the wording in the survey. See Appendix A for original question wording.
} 
columns $2 \mathrm{a}$ through $2 \mathrm{c}$ and the treatment in row (c) to have negative effects in these columns. As expected, the effects of the worthiness treatment presented in row (b) are positive and highly significant in columns 2 a through 2 c. Furthermore, in column 3 , we find that this treatment has a highly significant positive effect on perceptions that the recipients have no criminal record. The worthiness treatment presented in row (c) has negative effects (as expected) in columns $2 \mathrm{a}$ through $2 \mathrm{c}$. The effect is highly significant in column $2 \mathrm{a}$, marginally significant in column $2 \mathrm{c}$, and insignificant in column $2 \mathrm{~b}$.

Rows (d) and (e) present the effects of the other two worthiness treatments: describing recipients as, respectively, law-abiding and willing to share the aid they receive with others. As expected, the law-abiding treatment has a highly significant positive effect on perceptions that recipients have no criminal record, and the willing-toshare treatment has a highly significant positive effect on perceptions that recipients are willing to share their aid with others. In addition, these treatments have positive effects on other perceptions of worthiness (columns 2a-2c) which are significant at the fivepercent level in three cases and the ten-percent level in one case. Together, rows (b) through (e) establish that out treatments successfully manipulated perceptions of recipient worthiness.

Rows (f) through (h) present the effects of describing recipients as, respectively, needing short-term aid, currently working, and religious. These treatments correspond to perceptions measures that are ultimately relatively poorly explained. The $\mathrm{R}^{2}$ statistics in the columns explaining perceptions about recipients needing short-term aid, currently working, and being religious are the lowest among those in Table 2, ranging from 0.04 to 0.06 . Nonetheless, the short-term need for aid treatment has a highly significant positive effect on perceptions that recipients need short-term aid. The religious treatment is also successful with a highly significant positive effect on both perceptions that the recipients are religious and perceptions that the recipients are Republican.

Row (i) shows that describing Tuscaloosa as having Republican leanings significantly increases perceptions that the recipients are Republican. Row (j) presents the effects of stating that the city of Tuscaloosa is economically advantaged. As expected, this treatment has a highly significant positive effect on the perceived incomes of Tuscaloosa residents (col. 11), and it even affects the perceived income of the charity recipients (col. 
9). It also causes respondents to perceive a significantly lower fraction of city residents who are black-minus-white (column 10) and an insignificantly lower fraction of charity recipients who are black-minus-white (column 1). Finally, this treatment has a significant negative effect on perceptions that the recipients are Republican (col. 8).

Lastly, the row labeled "Black respondent" shows that in many columns, black respondents have significantly different perceptions than non-black respondents about charity recipients and Tuscaloosa residents. Compared to whites, black respondents perceive significantly fewer black charity recipients (col. 1) and perceive recipients as significantly more worthy (col. 2a-2c), but also less likely to be Republican (col. 8) and less economically advantaged (col. 9). Black respondents also perceive a significantly lower annual income for Tuscaloosa residents than whites perceive (col. 11).

Table 3 breaks out the sample by respondent race to further investigate the effects of our race and worthiness treatments on perceptions of the race and worthiness of the charity recipients. We present results for the whole sample (col. 1), the sample of nonblack respondents (col. 2), and the sample of black respondents (col. 3). Column 4 presents the results for the whole sample from a regression that includes an interaction term between respondent race and the race treatment and an interaction term between respondent race and the number of worthiness treatments. In this table, we use composite measures of the worthiness treatments and the worthiness perceptions. Recall from Table 2 that the worthiness treatments had effects on worthiness perceptions in the expected directions. Our composite measures of worthiness treatments and perceptions help us summarize these effects more compactly and give us more statistical power.

Our composite measure of worthiness treatments is the average number of worthiness treatments that the respondent was exposed to. There are four audio worthiness treatments: i) that poverty in Tuscaloosa is caused by bad choices, ii) that poverty in Tuscaloosa is caused by circumstances beyond individual control, iii) that the charity's recipients are law-abiding, and iv) that the charity's recipients are willing to share their own aid. ${ }^{10}$ Our derived measure of the mean of these treatments ranges from zero to one,

\footnotetext{
${ }^{10}$ The treatments not included in this measure were designed to manipulate perceptions other than worthiness - namely, perceptions about financial need and perceptions about background characteristics that we hypothesized might lead to social group loyalty.
} 
decreases by .25 for those who are assigned to (i) and increases by .25 for each of the conditions (ii), (iii) and (iv) to which a respondent is assigned.

Our composite measure of worthiness perceptions is the average of the responses to the five worthiness perceptions questions. There were five worthiness perceptions questions; namely the percentage of the charity's recipients who i) are poor mainly because of bad choices (reverse coded), ii) are poor because of reasons beyond individual control, iii) are willing to work hard in order to get ahead in life, iv) have a criminal record (reverse coded), and v) are willing to share their own aid. ${ }^{11}$ Our composite measure of worthiness perceptions is the average of these questions and ranges from zero to 100 .

Panel A presents regressions where the outcome variable is perceptions of the fraction of charity recipients who are black minus the fraction white. In every column of Panel A, the black photo treatment has a highly significant positive effect on the perceived fraction of charity recipients who are black-minus-white, with effects ranging from 21 to 29 percentage points. This confirms our conclusion from Table 2 that the race treatment successfully manipulated perceptions of race. The second row of Panel A presents the effect of the number of worthiness treatments on the racial perception variable. In the sample of black respondents, the number of worthiness perceptions has a marginally significant positive effect at the ten-percent level on the perceived percentage of blackminus-white aid recipients, while this effect is negative, but insignificant, for white respondents. Column 4 shows a significant interaction between the number of worthiness manipulations and respondent race, which indicates that the effect of the worthiness treatments is significantly different for black and non-black respondents. According to this interaction effect, people are more likely to think of worthy recipients as coming from their own racial group. This constitutes the first component of evidence for our first main finding, namely the existence of racial bias in perceptions.

Panel B presents regressions where the outcome variable is perceptions of the worthiness of the charity recipients. The first row shows that among non-blacks, black

\footnotetext{
${ }^{11}$ The perceptions measures not included in this worthiness perceptions measure correspond to treatment conditions not included in the worthiness manipulation measure. These perceptions questions were designed to check the effectiveness of treatments intended to manipulate financial need and background characteristics other than worthiness.
} 
photos have a highly significant negative effect on the perception of worthiness. In contrast, among blacks, black photos have a small and insignificant effect on the perception of worthiness. Moreover, column 4 shows that the interaction between respondent race and the black photo treatment is statistically significant. That is, black respondents seeing black photos rate aid recipients as more worthy than non-black respondents do, and this difference is statistically significant. This interaction effect mirrors the finding in Panel A of a significant interaction effect between respondent race and the number of worthiness treatments on race perceptions, and constitutes the second component of evidence for our first main finding, namely the existence of racial bias in perceptions. Row 2 of Panel B shows that in all columns, the worthiness treatments have significant positive effects on the perceived worthiness of the recipients, confirming our conclusion from Table 2 that our treatment successfully manipulated worthiness perceptions. In addition, non-black respondents' perceptions of worthiness are significantly more sensitive to our worthiness manipulations than the perceptions of black respondents, which would be consistent with non-blacks' being less familiar with aid recipients, and therefore having weaker priors about them.

Table 3 establishes our first main result - the existence of racial group loyalty bias in perceptions of worthiness of the recipients. Panel A shows that blacks who hear that the recipients are worthy are more likely than non-blacks who hear the same information to perceive that the recipients shown in the photos are black. Analogously, Panel B shows that blacks view black recipients as more worthy than white recipients while non-blacks view white recipients as more worthy. These findings are consistent with findings from the social categorization literature in social psychology suggesting that people tend to hold out-group members individually responsible for their own poor outcomes while people tend to attribute poor outcomes of "in-group" members to adverse external circumstances (Brewer and Miller 1996).

In the following sub-section we will examine the effects of our treatments on giving. We will show that while there are robust significant effects of the worthiness treatments on giving, there is no effect of recipient race on giving. Thus, while we find a form of racial group loyalty in perceptions about the worthiness of recipients, this bias does not translate into racial group loyalty in donations. 


\subsection{Treatment effects on giving}

Table 4 presents OLS regressions of giving in our experiment on our treatment conditions and demographic controls. The first column presents the effects of each treatment condition in the whole sample. The first row shows that the effect of the black photos is $-\$ 2.2$ with a standard error of $\$ 2.3$. This treatment effect is less than $4 \%$ of the mean offer of $\$ 59$ (see Table 1). The 95\%-confidence interval on this effect is $-\$ 6.7$ to $\$ 2.3$. Thus, at this level of confidence, we cannot rule out a negative effect of black photos of $11 \%$ of the $\$ 59$ mean. The next four rows of coefficients along with standard errors in column 1 present the effects of the worthiness treatments. When the worthiness treatments are included separately, their effects are generally in the expected direction, but only the "shares own aid with others" treatment has a statistically significant effect on giving. Finally, the remaining treatment conditions have small and statistically insignificant effects.

In the second column, we show the effect of the average of the four worthiness treatments rather than showing the effect of each worthiness treatment separately. We find that the combined effect of the worthiness treatments is positive and significant at the five-percent level. Respondents who hear four worthiness treatments describing the recipients as worthy give, on average, $\$ 11.0$ more than those who hear the four alternative treatments that describe recipients as unworthy. This establishes our second main result, namely that there is a causal effect of perceived worthiness on giving.

Columns 3 and 4 present the same regression as in column 2, but separately for nonblack and black respondents, respectively. In both columns the effect of black photos is small and statistically insignificant, but relatively precisely estimated. The effect of the worthiness treatments is positive and statistically significant for non-black respondents but negative and not statistically significant for black respondents. This null finding among blacks may reflect the fact that, among blacks, the number of worthiness treatments has a weaker effect on worthiness perceptions than among non-blacks (see Table 3). None of the other treatment effects are significant at the 5 percent level. 
Finally, column 5 presents a regression of giving on the same variables as in columns 3 and 4 but with interaction effects included, using the whole sample. As with the other regressions, this column shows a small, statistically insignificant, and relatively precisely estimated effect of the race treatment. The combined effect of the worthiness treatments is $\$ 13.4$ and is significant at the five-percent level. Neither of the interaction effects and none of the other treatment effects are significant at the five-percent level or better. ${ }^{12}$ This column establishes our third main result - the absence of significant racial bias in giving. Both the main effect of the black picture treatment and the interaction effect of the black picture treatment with black respondent are relatively small in magnitude, and neither is statistically significant. The main effect, which is more precisely estimated than the interaction effect, indicates that non-black respondents give $-\$ 2.3$ less after seeing black pictures, with a $95 \%$-confidence interval from $-\$ 7.3$ to $\$ 2.8$. The interaction effect of $\$ 0.4$ indicates that the reaction of black respondents to the black picture treatments is almost identical to the reaction of non-blacks, though the standard error of $\$ 5.3$ limits our ability to detect moderate amounts of racial bias.

Table 5 examines the effects of race and worthiness perceptions (as opposed to treatments) on giving. The independent variables here are identical to the dependent variables in Table 3 and are measured on scales from 0 to 100. Columns 1 and 3 present OLS regressions of giving on the perceived fraction of welfare recipients who are blackminus-white and the average response to the five worthiness perceptions questions, controlling for the other treatments and demographic variables. Note that these measures may be endogenous to respondents' donation decisions because i) perceptions may have formed in response to unobserved variables that also affect giving and ii) we measure perceptions after respondents decide how much to give to the recipients so stated preferences may to some extent merely reflect behavior rather than cause it. Thus, in

\footnotetext{
${ }^{12}$ There is a marginally significant negative interaction effect between the number of worthiness treatments and respondent race in column (4), corresponding to the finding in columns (2) and (3) that among nonblacks there is a significant positive effect of the number of worthiness treatments while among blacks, there is no significant effect. This is analogous to findings reported elsewhere that groups with lower socioeconomic status, including non-whites compared to whites, place a lower monetary value on redistributing resources on the basis of recipient "worthiness" (Corneo and Fong 2008). This lower monetary value of justice for non-whites and other low SES groups is driven by the finding that the effect of beliefs that bad choices (rather than bad luck) cause poverty on opposition to redistribution is smaller in absolute value for non-whites and other lower-SES groups than it is for whites and other higher-SES groups.
} 
columns 2 and 4, we present instrumental variables estimates of the effects of exogenous race and worthiness perceptions. Here, we instrument the race and worthiness perceptions measures with the black photo treatment and the worthiness treatments.

Columns 1 and 2 present the OLS and IV estimates in the sample of non-blacks. We use this sample because we found that both the race and worthiness treatments had statistically significant effects on the corresponding perceptions measures in Table 3 among non-blacks (in the black sample, only the race treatment had significant effects). Additionally, only in the non-black sample did the worthiness treatments have a significant effect on giving in Table 4. Finally, an important policy concern is non-black discrimination against blacks. We have greater statistical power to detect such an effect in the sample of non-blacks than in the whole sample.

Columns 1 and 2 of Table 5 indicate that the effects of both endogenous and exogenous perceptions of recipient race on giving are close to zero and statistically insignificant. If the perceived fraction of recipients who are black minus the perceived fraction who are white increases by ten percentage points, giving in our experiment is unchanged in column (1) with a 95\%-confidence interval of $-\$ 0.8$ to $\$ 0.8$. In column 2 , a ten-percentage point increase in our racial perceptions measure increases giving by $\$ 0.7$ with a $95 \%$-confidence interval of $-\$ 2.1$ to $\$ 3.6$. Recall that these results are from giving out of a total amount of $\$ 100$, where the mean gift is about $\$ 60$. In contrast, both the OLS and the IV estimates of the worthiness perceptions are positive and significant (at the one- and five-percent levels, respectively). The IV estimate is noteworthy in at least two respects. First, it allows us to scale the effect of the worthiness treatments in terms of worthiness perceptions, and this reveals that the treatment effect is large in economic terms: a ten percentage point increase in the average perceived worthiness of recipients increases giving by $\$ 8.6$. Second, the IV estimate is larger than the OLS estimate. Our interpretation of this finding is that the worthiness perceptions measures are likely poorly measured. If there is measurement error, then the OLS estimates are biased toward zero. The IV estimates, in contrast, do not suffer from attenuation bias induced by measurement error. Thus, our IV estimates address both the endogeneity and measurement error problems that are likely to be present in the OLS estimates. 
Columns 3 and 4 present OLS and IV estimates in the whole sample, with the race and worthiness perceptions measures interacted with respondent race. The first two rows show the effects of the race and worthiness perceptions on giving among non-blacks. As expected, both the OLS and IV estimates are similar to those of columns 1 and 2. The third and fourth rows present the interactions between the perceptions variables and a dummy for a black respondent. The interaction terms show that the effects of the perceptions variables among blacks are smaller than these same effects among nonblacks, but these differences are not statistically significant.

\subsection{Robustness checks}

In Table 6, we investigate the robustness of the two main results from Table 4 - namely that recipient race has a statistically insignificant effect on giving and that the combined effect of our worthiness manipulations has a significant positive effect. As before, we focus on the results for non-blacks because (i) this sample provides the most statistical power to detect racial bias in giving against blacks and (ii) the effect of worthiness on giving was driven by the non-black subsample. Each row of Table 6 presents a single regression of giving in our experiment on the black photo treatment and the average number of worthiness treatments. The first row reproduces the regression that was presented in column 3 of Table 4. Using the sample of non-black respondents, this baseline regresses giving in our experiment on the black photo treatment, the average number of worthiness treatments, dummies for the remaining treatments, and demographic controls. Each subsequent row presents a regression that is identical to the baseline regression in all but one respect. The second row is identical to the first except that it uses the whole sample. The third row uses whites only. The specifications and samples in rows 4 and 5 are the same as in row 1, except that they use ordered probit and censored regression, respectively. Rows 6 and 7 are the same as row 1 except that row 6 omits the demographic controls while row 7 includes additional controls. The additional controls included in row 7 are the perceived effectiveness of the charity (measured as the fraction of dollars donated to the charity that reach needy recipients), the self-reported importance of "helping others in need", and the self-reported importance of "earning a lot 
of money". These additional controls are not included in our baseline regression because they could be endogenous. Rows 8, 9, and 10 are the same as row 1 except that the dependent variables are, respectively, hypothetical giving, self-reported preference for government spending on the poor in Tuscaloosa, and self-reported preference for charitable spending on the poor in Tuscaloosa.

The first column of Table 6 presents the effect of the black photo treatment in each of these regressions. In every case, the effect of the race treatment is small and statistically insignificant. Column 2 presents the effects of the average number of worthiness treatments. In rows 1-7, where the dependent variable is giving in the experiment, the effect of the number of worthiness treatments is positive and significant at the five- or one-percent level. In the OLS regressions where the outcome variable is giving, the magnitude of the effect of hearing four worthiness treatments compared to hearing none of them ranges from $\$ 11$ to $\$ 16$; while in the censored regression, the magnitude is $\$ 25.4$. In rows 8-10, the outcome variables are the non-behavioral measures of generosity to charity recipients. The number of worthiness manipulations has a significant effect on support for government spending on the poor in Tuscaloosa (row 9), but no significant effect on hypothetical charitable giving (row 8). The effect of the number of worthiness manipulations on self-reported preferences for charitable spending on the poor in Tuscaloosa (row 10) was just short of marginally significant with a p-value of 0.104 . Recall that for these alternative dependent variables, there is no evidence of racial bias, either.

\subsection{External validity check}

How well might the results of our experiment generalize to natural giving outside of the experiment? One way to investigate the external validity of our result is to estimate the extent to which giving in our experiment corresponds to total charitable giving in the previous calendar year. In unreported results, we find that total charitable giving in 2005 has a statistically significant positive effect on giving in the experiment. However, a drawback of this simple regression is that measurement error in charitable giving leads attenuation bias in the estimated effect. Hence, it does not provide a good estimate of the 
sensitivity of giving in the experiment to total charitable giving. As a validity check that circumvents attenuation bias from measurement error, we investigate whether demographic characteristics that predict total charitable giving in 2005 similarly predict giving in our experiment. Table 7 presents this analysis.

Column 1 regresses giving during our experiment measured in dollars on respondent demographic characteristics. Column 2 regresses a transformed measure of total charitable giving in 2005 on the same demographic characteristics included in column 1. To make the dependent measures in columns 1 and 2 comparable, we first topcode total charitable giving in 2005 at $\$ 500$ so that the fraction of people giving the maximum amount is equal across the two measures. Then we divide total charitable giving in 2005 by 5 so that both giving measures range from zero to 100 . The key result from columns 1 and 2 is that the explanatory power of the demographic variables is higher in column 2 than in column 1. Moreover, the coefficients in column 2 tend to have a larger absolute value than the coefficients in column 1 , and the percent of the variation in giving that is explained by the demographic variables is roughly two times higher in column $2\left(\mathrm{R}^{2}=\right.$ .208) than in column $1\left(\mathrm{R}^{2}=.098\right)$. This is a first indication that giving during the experiment is somewhat less responsive to demographics that actual past charitable giving.

The regressions in columns 1 and 2 show that the demographic variables tend to have effects in the same direction on giving in our experiment and on past charitable giving; we do not see any demographic variables that have a significant positive effect in one of the columns and a significant negative effect in the other. However, since many of the demographic variables are highly correlated with each other, we investigate this general pattern in more detail in columns (3) and (4). We predict each type of giving with the demographic variables and then estimate the effect of: i) predicted total charitable giving in 2005 on actual giving during the experiment (column 3) and ii) predicted giving during the experiment on actual total charitable giving in 2005 (column 4). That is, we regress each type of giving on the linear combination of demographic variables that best predicts the other type of giving. This is a check of how well the combination of demographic variables that best explains one type of giving explains the other type of giving. 
Column 3 shows that if predicted charitable giving in 2005 increases by one, then actual giving in our experiment increases by $\$ 0.43$. That is, giving in the experiment is $43 \%$ as responsive as past charitable giving to the demographics that predict charitable giving. Column 4 estimates this responsiveness by regressing charitable giving in 2005 on predicted giving in the experiment. This estimate says that past charitable giving is $118 \%$ as responsive as giving in our experiment to the demographic variables that predict giving in the experiment, or, inversely, that giving in the experiment is $85 \%$ as responsive to the demographic variables as past charitable giving. In summary, giving in our experiment is somewhere between $43 \%$ and $85 \%$ as sensitive to the demographic variables as charitable giving in the real world. These results suggest that perceptions of the worthiness of the poor may also have a greater effect on charitable giving in the real world than they had on giving during the experiment.

\section{Conclusion}

In this paper, we presented the results from an experiment that examines how charitable giving to the poor responds to the perceived race and worthiness of charity recipients. The experiment was conducted on a sample of about 1000 respondents that is broadly representative of the U.S. adult population. We showed an audiovisual presentation about a charity, the charity's recipients, and the city in which recipients were located to manipulate respondents' perceptions of recipient race and worthiness. Following the presentation, the respondents decided how to distribute $\$ 100$ between themselves and the charity. Subsequently, we asked the respondents about their perceptions of the race and worthiness of the charity's recipients, which confirmed that our treatments successfully manipulated the respondents' perceptions.

The experiment yielded three main results. First, we find a racial group loyalty effect on perceptions: respondents rate recipients as more worthy when shown pictures of recipients from their own racial group, and conversely, they perceive a higher fraction of recipients from their own racial group if the audio story describes recipients in more worthy terms. Second, respondents give significantly more if our audio treatment causes them to perceive the recipients as more worthy. Moreover, this effect is also large in 
economic terms; audio treatments that raise the perceived fraction of worthy recipients by 10 percentage points cause the respondents to increase their giving by $\$ 7.2$ relative to a mean level of giving of $\$ 58.7$. Third, we find no significant racial bias in giving. The race of the recipients shown in the pictures, while highly influential on race perceptions, did not significantly affect giving in the whole sample or in subsamples by respondent race. Moreover, black and non-black respondents also did not respond significantly differently in their giving upon to seeing pictures of black recipients. However, given the statistical precision of our estimates, we cannot rule out a moderate amount of racial bias, but we can rule out at the $5 \%$ level that seeing pictures of black recipients causes non-black respondents to decrease giving by more than $\$ 7.4$ on a mean of $\$ 60.0$.

We do not believe that our failure to find racial discrimination in giving contradicts prior evidence of discrimination and racial group loyalty. There are at least three reasons for this. First, our evidence is from a different time period than prior evidence on racial effects in individual demands for redistribution. It is possible that racial effects may be lower now simply because racism in general has been decreasing over time in the United States. Racial effects may also be lower now than at other times because of domainspecific reasons: Much of the evidence of racial discrimination in redistributive politics in the United States comes from times when there was public anger about the former AFDC program and debate about welfare reform (see, e.g., Gilens 1999). It seems plausible that during politically turbulent times in countries where racial minorities belong to lower socioeconomic classes, racial discrimination can flare up naturally or even be manufactured by political entrepreneurs (Glaeser 2005). Second, there may be racial discrimination in individual demands for redistribution that our study does not detect. Our results are not precise enough to rule out moderate amounts of racial discrimination. Furthermore, despite the methodological advantages of our study - namely, using randomly varied perceptions as the independent variables and real behavior as the outcome variable - there are some disadvantages. In particular, respondents in our study were forced to make their donation decisions in a somewhat artificial setting, and they may have also suspected that they were being studied. Both of these factors may have affected our results. Third, even if there were currently no racial biases in individual charitable behavior and individual demands for redistribution, it seems likely that racial 
inequality in socioeconomic outcomes would persist as a legacy from prior discrimination. That is, merely avoiding discriminatory behavior in one instance, or even ending it more broadly, seems unlikely to erase the cumulative effects of prior discrimination. Thus, a lack of racial discrimination in our research does not imply that racial discrimination in society has been eradicated or that racial inequality is a smaller problem than previously thought. 


\section{References}

Alesina, A., Angeletos, G.-M., 2005. Fairness and redistribution: US versus Europe. American Economic Review 95, 960-980.

Alesina, A., Baqir, R., Easterly, W., 1999. Public goods and ethnic divisions. Quarterly Journal of Economics 114, 1243-1284.

Alesina, A., Giuliano, P., 2009. Preferences for Redistribution. Handbook of Social Economics. Forthcoming.

Alesina, A., Glaeser, E., Sacerdote, B., 2001. Why doesn't the United States have a European-style welfare state? Brookings Papers on Economic Activity 0, 187278.

Bénabou, R., Tirole, J., 2006. Belief in a Just World and Redistributive Politics. Quarterly Journal of Economics 121, 699-746.

Bohnet, I., Frey, B.S., 1999. Social distance and other-regarding behavior in dictator games: Comment. American Economic Review 89, 335-339.

Bowles, S., Gintis, H., 2004. The evolution of strong reciprocity: cooperation in heterogeneous populations. Theoretical Population Biology 65, 17-28.

Brewer, M.B., Miller, N., 1996. Intergroup Relations. Pacific Grove: Brooks/Cole Publishing Company.

Camerer, C., 2003. Behavioral Game Theory: Experiments in Strategic Interaction. Princeton: Princeton University Press.

Corneo, G., Fong, C.M., 2008. What's the Monetary Value of Distributive Justice? Journal of Public Economics 92, 289-308.

Corneo, G., Grüner, H.-P., 2002. Individual preferences for political redistribution. Journal of Public Economics 83, 83-107.

Croson, R., Shang, J., 2005. Field experiments in charitable contribution: The impact of social influence on the voluntary provision of public goods. Mimeo.

DellaVigna, S., List, J.A., Malmendier, U., 2009. Testing for Altruism and Social Pressure in Charitable Giving. Mimeo.

Deutsch, M., 1985. Distributive justice. New Haven: Yale University Press.

Durante, R., Putterman, L., 2008. Preferences for Redistribution and Perception of Fairness: An Experimental Study. Mimeo.

Eckel, C.C., Grossman, P.J., 1996. Altruism in anonymous dictator games. Games and Economic Behavior 16, 181-191.

Eckel, C.C., Grossman, P.J., 2008. Subsidizing charitable contributions: A field test comparing matching and rebate subsidies. Experimental Economics 11, 234-252.

Falk, A., 2007. Gift exchange in the field. Econometrica 75, 1501-1511.

Fehr, E., Fischbacher, U., Gächter, S., 2002. Strong reciprocity, human cooperation and the enforcement of social norms. Human Nature 13, 1-25.

Frey, B., Meier, S. 2004. Social comparisons and pro-social behavior: Testing 'conditional cooperation' in a field experiment. American Economic Review 94, 1717-22.

Fong, C.M., 2001. Social preferences, self-interest, and the demand for redistribution. Journal of Public Economics 82, 225-246. 
Fong, C.M., 2007. Evidence from an experiment on charity to welfare recipients: Reciprocity, altruism and the empathic responsiveness hypothesis. Economic Journal 117, 1008-1024.

Fong, C.M., Bowles, S., Gintis, H., 2006. Strong reciprocity and the welfare state. In: Kolm, S.-C. and Ythier, J.M. (Eds), Handbook on the economics of giving, altruism and reciprocity, volume 2. Amsterdam: Elsevier, 1440-1464.

Fong, C.M., Luttmer, E.F.P., 2009. What determines giving to Hurricane Katrina victims? Experimental evidence on racial group loyalty. American Economic Journal: Applied Economics 1, 64-87.

Gilens, M., 1999. Why Americans hate welfare. Chicago: University of Chicago Press.

Gintis, H., 2000. Strong Reciprocity and Human Sociality. Journal of Theoretical Biology 206, 169-179.

Glaeser, E.L., 2005. The Political Economy of Hatred. Quarterly Journal of Economics, $120,45-86$.

Heclo, H., 1986. The political foundations of antipoverty policy. In: Danzinger, S.H. and Weinberger, D.H. (Eds.), Fighting Poverty. Cambridge: Harvard University Press, 312-340.

Hoffman, E., McCabe, K., Shachat, J., Smith, V., 1994. Preferences, property rights and anonymity in bargaining games. Games and Economic Behavior 7, 346-380.

Karlan, D., List, J.A., 2007. Does price matter in charitable giving? Evidence from a large-scale natural field experiment. American Economic Review 97, 1774-1793.

Konow, J., 2003. Which Is the Fairest One of All?: A Positive Analysis of Justice Theories. Journal of Economic Literature 41, 1186-1237.

Landry, C., Lange, A., List, J.A., Price, M.K., Rupp, N.G., 2006. Toward an understanding of the economics of charity: Evidence from a field experiment. Quarterly Journal of Economics, 121, 747-82.

Lee, W., Roemer, J.E., 2006. Racism and redistribution in the United States: A solution to the problem of American exceptionalism. Journal of Public Economics 90, 1027-1052.

Lindqvist, E., Östling, R. 2009. Identity and Redistribution. Mimeo.

List, J.A., Price, M.K., 2009. The role of social connections in charitable fundraising: Evidence from a natural field experiment. Journal of Economic Behavior and Organization 69, 160-169.

Luttmer, E.F.P., 2001. Group loyalty and the taste for redistribution. Journal of Political Economy 109, 500-528.

Meer, J., 2009. Brother, Can You Spare a Dime? Peer Effects in Charitable Solicitation. Mimeo.

Piketty, T., 1995. Social mobility and redistributive politics. Quarterly Journal of Economics 110, 551-584.

Rabin, M., 1993. Incorporating fairness into game theory and economics. American Economic Review 83, 1281-1292.

Shayo, M., 2009. A Model of Social Identity with an Application to Political Economy: Nation, Class and Redistribution. American Political Science Review, forthcoming.

Small, D.A., Loewenstein, G., 2003. Helping a victim or helping the victim: Altruism and identifiability. Journal of Risk and Uncertainty 26, 5-16. 
Walster, E.G., Walster, W., Berscheid, E., 1978. Equity: Theory and Research. Boston: Allyn and Bacon.

Weiner, B., 1995. Judgments of Responsibility. New York: The Guilford Press.

Williamson, J.B., 1974. Beliefs about the motivation of the poor and attitudes toward poverty policy. Social Problems 21, 734-747. 


\section{Appendix A: Charity Survey Instrument}

- Text that is notes is bold and in brackets. Text that is the name of a question or a variable name is in brackets and capital letters.

- Audio text that respondents hear is in italics; all other text the respondents read.

- For multiple choice questions they were given radio buttons to click on, in this appendix that feature shows up as numbered options [1], [2], [3], this is different from audio treatments which are distinguished (0), (1).

- Separating lines correspond to new screens.

- [CHARITY] was replaced in both the text and the audio with either the words "Salvation Army" or the words "Temporary Emergency Services" depending on the treatment.

- There are a total of 11 experimental treatments: [CHARITY], the name of the charity shown in the presentation, [BLACK PICTURE], the predominant race of the people shown in the pictures, and the nine audio treatments: (1) [CITY IS REPUBLICAN], (2) [CITY IS ECONOMICALLY ADVANTAGED], (3) [REASON FOR POVERTY BEYOND CONTROL], (4) [REASON FOR POVERTY BAD CHOICE], (5) [RELIGIOUS], (6) [SHORT-TERM NEED FOR AID], (7) [CURRENTLY WORKING], (8) [WILLING TO SHARE OWN AID WITH OTHERS], and (9) [LAW-ABIDING].

-- Main Questionnaire --

This is a study conducted by researchers at Carnegie Mellon University and Harvard University. The general topic is assistance to the poor and other issues facing America.

Thank you for your participation!

PART I. BACKGROUND ABOUT THE WORK OF A FOOD PANTRY IN [TOWN]

Presentation about [CHARITY] in Tuscaloosa, AL

Shortly, you will see a brief presentation about the work of [CHARITY] in [TOWN], AL.

Please have the volume on your computer or TV adjusted so that you can clearly hear the speaker's voice that goes with the slides.

To respect their privacy, we have obscured the identities of the people shown in the slides.

During the presentation, the "Continue" button only becomes active after the speaker has finished.

[Respondents view first pair of pictures. These are two pictures of the city of Tuscaloosa itself, shown side by side. The first picture is the same independent of the black picture treatment. (It shows a black and a white cyclist in the background). In the second picture, a black passerby is shown in the black picture treatment and a white passerby otherwise. Respondents hear the following audio text.]

The City of Tuscaloosa, AL

This is a slide show about Tuscaloosa, some of its poor people, and a charity that helps them. Tuscaloosa is a small city in Alabama.

[CITY IS REPUBLICAN]:

0. Compared to the rest of Alabama more people in Tuscaloosa vote for the Democratic Party

1. Like the rest of Alabama, people in Tuscaloosa vote overwhelmingly for the Republican Party

[CITY IS ECONOMICALLY ADVANTAGED]:

0 . Tuscaloosa is relatively disadvantaged, with a poverty rate that is almost twice as high as in the rest of the country.

1. Tuscaloosa is relatively advantaged, with a per capita income that is more than $5 \%$ higher than the rest of the state. 
To respect their privacy, we have obscured the identities of the people in the photographs.

[Respondents view second pair of pictures, again shown side by side. The first picture shows a person entering a thrift store. This person is black in the black picture treatment and white otherwise. The second picture shows two individuals, one black and one white, inside the thrifts store. Respondents hear the following audio text.]

The Poor in Tuscaloosa

Many poor people in Tuscaloosa receive both welfare from the government and food and other goods from a variety of charities.

[If REASON FOR POVERTY BEYOND CONTROL $=0$ and REASON FOR POVERTY BAD CHOICE=1]: Many of these people use welfare and charitable assistance because of bad choices in their personal lives such as lack of effort or substance abuse.

Generally the recipients are unhappy about their situation and wish they had more money.

Many of them wish they could rely on more generous assistance from the government and charities.

[If REASON FOR POVERTY BEYOND CONTROL=1 and REASON FOR POVERTY BAD CHOICE=0]:

Many of these people use welfare and charitable assistance because of circumstances beyond their control such as bad luck.

Generally the recipients are unhappy about their situation and wish they had more money.

Many of them try to get a job that pays enough for them to stand on their own feet and no longer rely on assistance from the government and charities.

[If REASON FOR POVERTY BEYOND CONTROL=0 and REASON FOR POVERTY BAD CHOICE=0]:

The reasons why these people use government welfare and charitable assistance vary widely. Often it is a mixture of factors including bad choices in their personal lives such as lack of effort or substance abuse, and circumstances beyond their control such as bad luck.

Generally the recipients are unhappy about their situation and wish they had more money.

[Note the combination REASON FOR POVERTY BEYOND CONTROL=1 and REASON FOR POVERTY BAD $\mathrm{CHOICE}=1$ does not occur]

[RELIGIOUS]:

0. [NOTHING SAID]

1. Many of them pray to God regularly to ask Him for help.

[Respondents view third pair of pictures, again shown side by side. Both pictures are of people receiving aid from [CHARITY]. Under the black picture treatment, all individuals shown are black. Otherwise, all individuals shown are white. Respondents hear the following audio text.]

The work of [CHARITY]

[CHARITY] in Tuscaloosa is one of the charities that help welfare recipients and other poor people in Tuscaloosa.

[SHORT-TERM NEED FOR AID]

0 . It provides food and other goods to the poor, many of whom use this kind of help for long periods of time.

1. It provides food and other goods to the poor, many of whom only use this kind of help for short periods of time when it is absolutely necessary.

[CURRENTLY WORKING]:

0 . Providing enough assistance is more difficult on the busy days just before many people will receive their next government benefit check. 
1. Providing enough assistance is more difficult on the busy days just before many people will receive their next paycheck.

[WILLING TO SHARE OWN AID WITH OTHERS]:

0 . During these busy days, many of the usual recipients get worried and become competitive with others in line for assistance.

1. During these busy days, many of the usual recipients get worried, but they are willing to share some of their allotment with others in need.

[Respondents view third pair of pictures, again shown side by side. Both pictures are of people receiving aid from [CHARITY]. Under the black picture treatment, all individuals shown are black. Otherwise, all individuals shown are white. Respondents hear the following audio text.]

The people that receive help from [CHARITY]

Ideally, the recipients will obtain jobs that pay well enough that they no longer need assistance from charities, but in practice this is often hard for a variety of reasons.

[LAW-ABIDING]:

0 . For example, many employers are reluctant to hire people who have a criminal record.

1. For example, many employers are reluctant to hire them.

In the meantime, organizations like [CHARITY] provide crucial assistance to welfare recipients and other poor people in Tuscaloosa. [CHARITY] couldn't achieve this without many generous charitable contributions and help from volunteers.

[SOUND CHECK] How well could you hear the speaker's voice in the presentation you just saw?

I didn't hear any sound....

I heard some sound but couldn't understand what she was saying .....

The speaker's voice was clear and understandable

[IF RESPONDENT SELECTS 1 (“DIDN'T HEAR ANY SOUND”) OR 2 (“COULDN'T UNDERSTAND WHAT SHE WAS SAYING”) SURVEY SKIPS TO DISPLAY SCREEN AT THE BEGINNING OF PART IV.

\section{PART II. DECISION-MAKING TASK}

\section{Decision-making task}

Now, you are going to make a decision involving [CHARITY] in Tuscaloosa. Please note that all information we give you is true and all payments will be made exactly as stated. Please think carefully about your decision because one out of every 10 participants in this study will have his or her decision carried out with real money.

We will give $\$ 100$ to one out of every 10 participants in this study. We ask you to decide in advance how much of this $\$ 100$, if any, you would like to give to [CHARITY] in Tuscaloosa. You can give any amount you wish, including nothing. If you are selected, this $\$ 100$ is yours, and you are free to keep or to give away any amount you wish, including nothing. While many people give some away, we expect that most people will keep at least some of this amount for themselves.

If you are randomly selected to receive $\$ 100$, we will send the amount that you want to donate, if any, to [CHARITY] in Tuscaloosa. The amount that you decide to keep for yourself will be credited to your Knowledge Networks account (you get 1000 bonus points for each dollar you decide to keep).

If you decide to donate money, [CHARITY] in Tuscaloosa will mail you a note to confirm that we sent them exactly the amount you specified.

The random selection works as follows. If the first number of the Pick3 draw of the Louisiana State Lottery on [LOTTERYDATE] is [LOTTERYNumBeR], then we will carry out your decision. Because numbers in the Pick3 game lie between 0 and 9 , you have a 1 in 10 chance that we will carry out your decision. If you wish, you will be able to find the winning number on http://www.louisianalottery.com. However, this is not necessary. If your number is drawn, we will automatically carry out your decision. 
[GIVING DURING EXPERIMENT] Now, please decide how much of your $\$ 100$ you want to give to [CHARITY] for its services to welfare recipients and other poor people in Tuscaloosa in the event that you are randomly selected to receive $\$ 100$.

If the first number of the Pick3 draw on [LOTTERYDATE] is [LOTTERYNumBeR],

I want \$

Tuscaloosa.

to be sent to [CHARITY] for its services to welfare recipients and other poor people in

[CONFIRM] If the first number of the Pick3 draw on [LOTTERYDATE] is [LOTTERYNUMBER], \$[AMOUNT FROM ABOVE] will be sent to [CHARITY] for its services to welfare recipients and other poor people in [TOWN], and \$[100 AMOUNT FROM ABOVE] will be sent to you as a credit of [1000*REMAINDER] bonus points to your Knowledge Networks account.

Is this correct?

Yes

No, I would like to change my answer......

\section{[SHOWN GIVING DURING EXPERIMENT AGAIN IF RESPONDENT SELECTS “No” IN CONFIRM]}

[HYPOTHETICAL GIVING].

[SHOWN FOLLOWING IF GIVING =0]

Suppose that [CHARITY] in Tuscaloosa had mailed a letter to your home describing the plight of welfare recipients and other poor people in Tuscaloosa and had asked you for a donation. How much, if anything, would you have given?

[GIVEN A NUMBER BOX WITH RANGE 0-99999]

\section{[SHOWN FOLLOWING IF GIVING >0]}

Suppose that you had not just given \$[GIVING] to [CHARITY]. Instead, suppose that [CHARITY] in Tuscaloosa had mailed a letter to your home describing the plight of welfare recipients and other poor people in Tuscaloosa and had asked you for a donation. How much, if anything, would you have given?

[GIVEN A NUMBER BOX WITH RANGE 0-99999]

PART III. QUESTIONS ABOUT THE FOOD PANTRY RECIPIENTS

Factual questions about recipients of [CHARITY]

From the information presented earlier, you may have learned more about [CHARITY] in Tuscaloosa. Now, we'd like to ask you some questions about [CHARITY] and about the characteristics of people who receive aid from [CHARITY] in Tuscaloosa.

It is very important to us that you answer these questions as carefully as possible. We will give you 1500 bonus points for completing this section of the study. In return, we would appreciate it if you would put in extra effort to answer these questions as carefully as possible.

[GIVEN A NUMBER BOX WITH RANGE 0-99999]

\section{[INCOME OF CHARITY RECIPIENTS]}

We'd like to know what you think the median household income is for recipients of [CHARITY] in Tuscaloosa. The median (i.e., middle) household income is the income where half of the [CHARITY] recipients' households are richer and half are poorer.

As a reference, the Federal poverty standard is currently about $\$ 20,000$ for a family of 4 , and exactly half of all households in the U.S. have an income less than $\$ 44,000$ per year. 
My best guess is that the median household income of recipients of [CHARITY] in Tuscaloosa is about \$ , 000 per year.

[GIVEN A NUMBER BOX WITH RANGE 0 TO 100]

[PERCENT OF RECIPIENTS WILLING TO WORK HARD]

As your best guess, what percentage of recipients of [CHARITY] in Tuscaloosa are willing to work hard in order to get ahead in life?

[GIVEN A NUMBER BOX WITH RANGE 0 TO 100]

[PERCENT OF RECIPIENTS WITH A CRIMINAL RECORD]

As your best guess, what percentage of recipients of [CHARITY] in Tuscaloosa have a criminal record?

[GIVEN A NUMBER BOX WITH RANGE 0 TO 100]

[PERCENT OF RECIPIENTS ATTENDING CHURCH]

As your best guess, what percentage of recipients of [CHARITY] in Tuscaloosa attend religious services almost every week?

[GIVEN A NUMBER BOX WITH RANGE 0 TO 100]

[REASON FOR POVERTY]

As you recall, the recipients of [CHARITY] in Tuscaloosa are poor - they are welfare recipients and other poor people.

As your best guess, what percentage of recipients of [CHARITY] in Tuscaloosa are poor mainly because of reasons beyond their control?

[GIVEN A NUMBER BOX WITH RANGE 0 TO 100]

As your best guess, what percentage of recipients of [CHARITY] in Tuscaloosa are poor mainly because of bad choices in their personal lives?

[GIVEN A NUMBER BOX WITH RANGE 0 TO 100]

[PERCENT OF RECIPIENTS WILLING TO SHARE ASSISTANCE]

As your best guess, what percentage of recipients of [CHARITY] in Tuscaloosa would be willing to share some of the assistance they receive with others in need?

[GIVEN A NUMBER BOX WITH RANGE 0 TO 100]

[PERCENT OF RECIPIENTS WHO WORK]

As your best guess, what percentage of adult recipients of [CHARITY] in Tuscaloosa currently work at least 20 hours per week for pay?

[GIVEN A NUMBER BOX WITH RANGE 0 TO 100]

[PERCENT OF RECIPIENTS RECEIVING ASSISTANCE SHORT TERM]

As your best guess, what percentage of recipients of [CHARITY] in Tuscaloosa rely on charity assistance only for a short period of time (less than six months) in order to overcome a period of difficulty?

[GIVEN A NUMBER BOX WITH RANGE 0 TO 100]

[PERCENT OF RECIPIENTS WHO VOTED FOR BUSH]

Now, we'd like to ask you about recipients of [CHARITY] in Tuscaloosa who voted in the 2004

Presidential election. As your best guess, what percentage of these people voted for George W. Bush?

[GIVEN A NUMBER BOX WITH RANGE 0 TO 100]

[INCOME OF TUSCALOOSA POPULATION] 
As your best guess, what is the median household income in Tuscaloosa? The median (i.e., middle) household income in the city is the household income where half of the households in the city are richer and half are poorer. (The median household income in the whole of the U.S. is $\$ 44,000$ per year).

The median household income in Tuscaloosa is about $\$ \_, 000$ per year.

\section{[PART IV. SURVEY QUESTIONS]}

Survey questions

Now we'd like to ask you some survey questions about poverty and other issues. There are no right or wrong answers. Please simply answer the questions as truthfully as you can.

\section{[GOVERNMENT SPENDING ON RECIPIENTS IN TUSCALOOSA]}

Compared to the current level of spending, do you think the government should spend more or less of its budget on helping welfare recipients and other poor people in Tuscaloosa?

\begin{tabular}{|c|c|c|c|c|c|c|}
\hline $\begin{array}{c}\text { Government } \\
\text { should spend } \\
\text { much LESS }\end{array}$ & & $\begin{array}{c}\text { Government } \\
\text { should spend } \\
\text { the same }\end{array}$ & & & $\begin{array}{c}\text { Government } \\
\text { should spend } \\
\text { much MORE }\end{array}$ \\
\hline [1] & [2] & {$[3]$} & {$[4]$} & {$[5]$} & {$[6]$} & {$[7]$} \\
\hline
\end{tabular}

[CHARITY SPENDING ON RECIPIENTS IN TUSCALOOSA]

Compared to their current level of spending, do you think that charities should spend more or less of their budgets on helping welfare recipients and poor people in Tuscaloosa?

\begin{tabular}{|c|c|c|c|c|c|c|}
\hline $\begin{array}{c}\text { Charities } \\
\text { should spend } \\
\text { much LESS }\end{array}$ & & $\begin{array}{c}\text { Charities } \\
\text { should spend } \\
\text { the same }\end{array}$ & & $\begin{array}{c}\text { Charities } \\
\text { should spend } \\
\text { much MORE }\end{array}$ \\
\hline [1] [2] & [3] & {$[4]$} & {$[5]$} & {$[6]$} & {$[7]$} \\
\hline
\end{tabular}

[CHARITY EFFECTIVENESS]

How effective do you think [CHARITY] in Tuscaloosa is at getting aid to needy recipients? More specifically, out of every $\$ 100.00$ that is donated to it, how many dollars do you think go to needy recipients?

[GIVEN A NUMBER BOX WITH RANGE 0 TO 100]

[PERSONAL CONNECTION TO POVERTY]

Do you personally know someone who receives or has received assistance from a charity?

Yes

No.

\section{[PREFERENCES FOR SOCIAL SPENDING]}

We are faced with many problems in this country, none of which can be solved easily or inexpensively. Below, we list two of these problems. For each one, please tell us whether you think we're spending too much money on it, too little money, or about the right amount.

Programs for the poor (e.g., "welfare" or programs like TANF, food stamps, and public housing)

\begin{tabular}{|c|l|l|l|l|c|}
\hline $\begin{array}{c}\text { Spending too } \\
\text { LITTLE }\end{array}$ & $\begin{array}{c}\text { Spending } \\
\text { about the } \\
\text { right amount }\end{array}$ & $\begin{array}{c}\text { Spending too } \\
\mathrm{MUCH}\end{array}$ \\
\hline
\end{tabular}
[1]
[2]
[3]
[4]
[5]
[6]
[7]

Social insurance programs (e.g. Social Security, Unemployment Insurance, and Medicare?). 


\begin{tabular}{|c|c|c|c|c|c|c|}
\hline $\begin{array}{c}\text { Spending too } \\
\text { LITTLE }\end{array}$ & 年 & $\begin{array}{c}\text { Spending } \\
\text { about the } \\
\text { right amount }\end{array}$ & & $\begin{array}{c}\text { Spending too } \\
\text { MUCH }\end{array}$ \\
\hline$[1]$ & {$[2]$} & {$[3]$} & {$[4]$} & {$[5]$} & {$[6]$} & {$[7]$} \\
\hline
\end{tabular}

[CHARITABLE GIVING TO KATRINA RELIEF]

What, approximately, is the total amount of money that you and people in your household have donated towards the Katrina relief effort?

[GIVEN A NUMBER BOX WITH RANGE 0 TO 999999]

\section{[CHARITABLE GIVING TO CHARITIES FOR POVERTY]}

[SHOWN FOLLOWING IF GIVING =0].

What, approximately, is the total amount of money that you and people in your household have donated in 2005 to charities that help poor people in the U.S.?

\section{[GIVEN A NUMBER BOX WITH RANGE 0 TO 999999]}

$\$$

\section{[SHOWN FOLLOWING IF GIVING >0].}

Not including any amount you may have given during his survey, what, approximately, is the total amount of money that you and people in your household have donated in 2005 to charities that help poor people in the U.S.?

$\$$

[GIVEN A NUMBER BOX WITH RANGE 0 TO 999999]

\section{[TOTAL CHARITABLE GIVING]}

What, approximately, is the total amount of money that you and people in your household donated towards all charitable causes in 2005 ?

[GIVEN A NUMBER BOX WITH RANGE 0 TO 999999]

$\$$

\section{[CHARITABLE GIVING TO CHARITIES FOR LOCAL POVERTY]}

Now, we'd like to ask about your charitable giving to help poor people in your local area. By "local area" we mean the greater metropolitan area of the town or city that you live in or near. If you live in a rural area and are not part of a greater metropolitan area, then "local area" means your county.

What, approximately, is the total amount of money that you and people in your household have donated in 2005 to charities that help poor people in your local area?

[GIVEN A NUMBER BOX WITH RANGE 0 TO 999999]

\section{[REASONS FOR POVERTY]}

Now, we would like to ask you about some of the possible reasons why people are poor.

For each of the possible reasons listed below, please tell us how important you believe it is in explaining why some people in this country are poor.

Failure of society to provide good schools for everyone

Not at all
important

[1]

[2]

[2]

(2)

\section{Somewhat} important

[4]

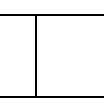

\begin{tabular}{|c|c|c|} 
& & $\begin{array}{c}\text { Extremely } \\
\text { important }\end{array}$ \\
\hline$[5]$ & {$[6]$} & {$[7]$}
\end{tabular}


Loose morals and substance abuse

Not at all
important

(2]

[1]

[2]

[3]

Somewhat

important

[4]

$[\sqrt{2}+2$

I

[5]

[6]

Extremely important

Failure of the economy to provide enough jobs

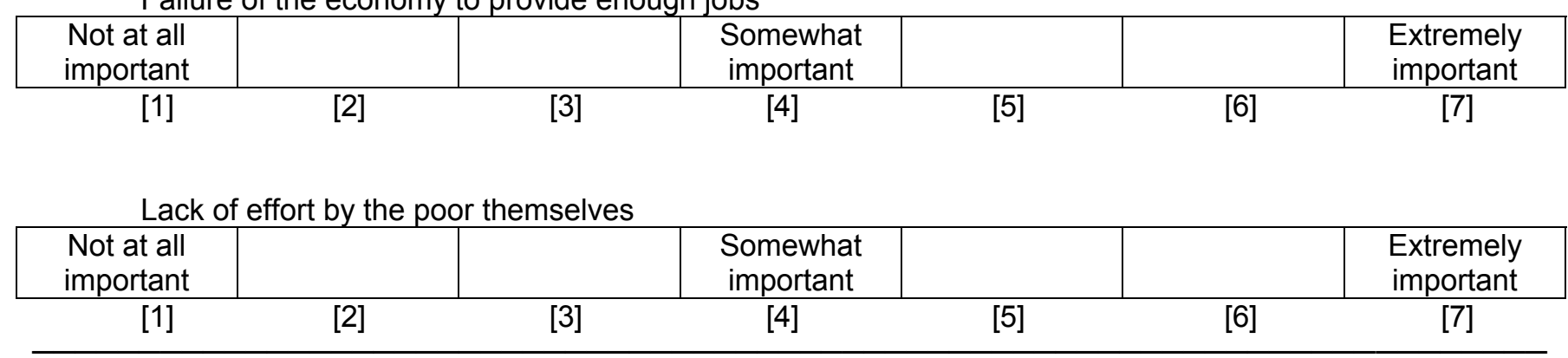

[LIFE PRIORITIES 1]

There are many important things in life, but some are more important than others. We are going to ask you about the five most important things from the list below.

First, what do you believe is the most important?

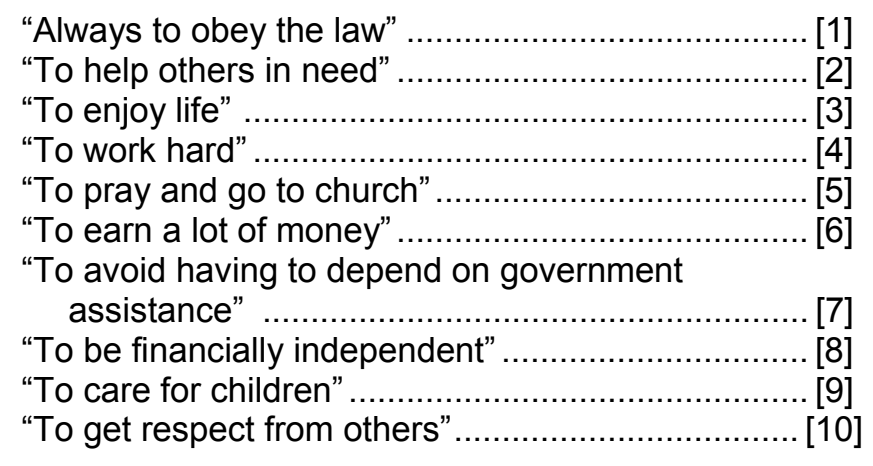

[LIFE PRIORITIES 2] What do you believe is second most important?

[SHOWN RESPONSES NOT SELECTED ABOVE]

[LIFE PRIORITIES 3] What do you believe is third most important?

[SHOWN RESPONSES NOT SELECTED ABOVE]

[LIFE PRIORITIES 4] What do you believe is fourth most important?

[SHOWN RESPONSES NOT SELECTED ABOVE]

[LIFE PRIORITIES 5] What do you believe is fifth most important?

[SHOWN RESPONSES NOT SELECTED ABOVE]

[PERCENT OF RECIPIENTS WHO ARE (RACE)]

As your best guess, what percentage of recipients of [CHARITY] in [TOWN] are:

White $\%$

African American $\frac{}{\%} \%$ 
[SHOWN NUMBER BOXES WITH RANGE 0 TO 100 SUMMING TO 100; RESPONDENTS WERE SHOWN SUM BOX FOR AMOUNTS ENTERED AND PROGRAM RECORDED HOW MANY TIMES RESPONDENT GOT A WARNING ABOUT PERCENTAGES NOT EQUALING 100]

\section{[PERCENT OF RECIPIENTS WHO ARE (RACE)]}

As your best guess, what percentage of all residents of [TOWN] are:

White

African American

Another race $\%$ $\%$

[SHOWN NUMBER BOXES WITH RANGE 0 TO 100 SUMMING TO 100; RESPONDENTS WERE SHOWN SUM BOX FOR AMOUNTS ENTERED AND PROGRAM RECORDED HOW MANY TIMES RESPONDENT GOT A WARNING ABOUT PERCENTAGES NOT EQUALING 100]

\section{[SOCIAL CONTACTS]}

How often do you socialize with friends from the following racial and ethnic groups?

Caucasian Americans (Whites)

\begin{tabular}{|c|c|c|c|c|c|c|}
\hline Never & $\begin{array}{c}\text { Once a } \\
\text { year or less }\end{array}$ & $\begin{array}{c}\text { A few times } \\
\text { a year }\end{array}$ & $\begin{array}{c}\text { Once or } \\
\text { twice a } \\
\text { month }\end{array}$ & $\begin{array}{c}\text { Almost } \\
\text { every week }\end{array}$ & $\begin{array}{c}\text { Once a } \\
\text { week }\end{array}$ & $\begin{array}{c}\text { Everyday or } \\
\text { almost } \\
\text { everyday }\end{array}$ \\
\hline
\end{tabular}

[1]

[2]

[3]

[4]

[5]

[6]

[7]

African Americans

\begin{tabular}{|c|c|c|c|c|c|c|}
\hline Never & $\begin{array}{c}\text { Once a } \\
\text { year or less }\end{array}$ & $\begin{array}{c}\text { A few times } \\
\text { a year }\end{array}$ & $\begin{array}{c}\text { Once or } \\
\text { twice a } \\
\text { month }\end{array}$ & $\begin{array}{c}\text { Almost } \\
\text { every week }\end{array}$ & $\begin{array}{c}\text { Once a } \\
\text { week }\end{array}$ & $\begin{array}{c}\text { Everyday or } \\
\text { almost } \\
\text { everyday }\end{array}$ \\
\hline
\end{tabular}

[1]

[2]

[3]

[4]

[5]

[6]

[7]

People from other racial or ethnic groups

\begin{tabular}{|c|c|c|c|c|c|c|}
\hline Never & $\begin{array}{c}\text { Once a } \\
\text { year or less }\end{array}$ & $\begin{array}{c}\text { A few times } \\
\text { a year }\end{array}$ & $\begin{array}{c}\text { Once or } \\
\text { twice a } \\
\text { month }\end{array}$ & $\begin{array}{c}\text { Almost } \\
\text { every week }\end{array}$ & $\begin{array}{c}\text { Once a } \\
\text { week }\end{array}$ & $\begin{array}{c}\text { Everyday or } \\
\text { almost } \\
\text { everyday }\end{array}$ \\
\hline
\end{tabular}

[1]

[2]

[3]

[4]

[5]

[6]

[7]

[PERCEIVED RACIAL DISADVANTAGE]

Just in your opinion, how do the economic opportunities of African Americans compare to the economic opportunities of other Americans? Do African Americans get many fewer opportunities, about the same number, or many more opportunities than other Americans?

\begin{tabular}{|c|c|c|c|c|c|c|}
\hline $\begin{array}{c}\text { Many } \\
\text { FEWER }\end{array}$ & & $\begin{array}{c}\text { About the } \\
\text { same }\end{array}$ & & Many MORE \\
\hline$[1]$ & {$[2]$} & {$[4]$} & {$[5]$} & {$[6]$} & {$[7]$} \\
\hline
\end{tabular}

[ITEMIZE DEDUCTIONS]

Do you itemize deductions on your Federal taxes?

Yes

No......

Don't know

[STANDARD CLOSE]

Thinking about this topic, do you have any comments you would like to share?

[OPEN ENDED TEXT BOX PROVIDED] 
Figure 1: CDF of Giving During the Experiment

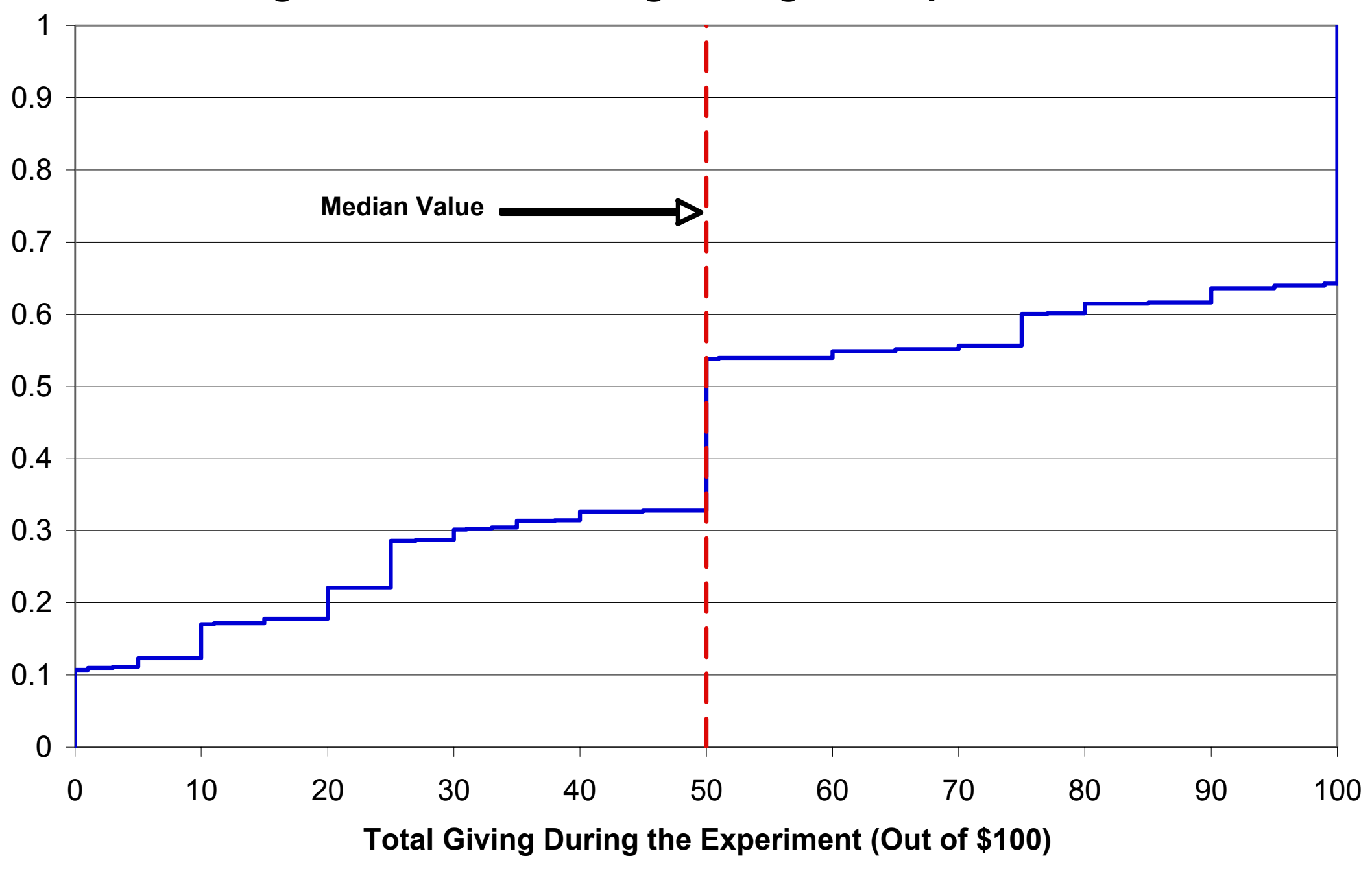


Table 1: Summary Statistics

\begin{tabular}{|c|c|c|c|c|c|}
\hline & Mean & S.D. & Min & Max & $\mathrm{N}$ \\
\hline \multicolumn{6}{|l|}{ Outcome Variables } \\
\hline Giving During the Experiment ( $\$$ out of $\$ 100$ ) & 58.7 & 37.2 & 0 & 100 & 982 \\
\hline Fraction Giving $\$ 100$ & 0.355 & 0.5 & 0 & 1 & 982 \\
\hline Fraction Giving $\$ 50$ & 0.209 & 0.4 & 0 & 1 & 982 \\
\hline Fraction Giving $\$ 0$ & 0.109 & 0.3 & 0 & 1 & 982 \\
\hline Fraction Giving Some Other Amount & 0.328 & 0.5 & 0 & 1 & 982 \\
\hline Hypothetical Giving (\$, topcoded at \$500) & 11.6 & 29.6 & 0 & 500 & 980 \\
\hline $\begin{array}{l}\text { Self-Reported Preference for Government Spending on Poor in } \\
\text { Tuscaloosa (1-7 scale) }\end{array}$ & 4.5 & 1.5 & 1 & 7 & 977 \\
\hline $\begin{array}{l}\text { Self-Reported Preference for Charity Spending on Poor in } \\
\text { Tuscaloosa (1-7 scale) }\end{array}$ & 4.6 & 1.2 & 1 & 7 & 972 \\
\hline \multicolumn{6}{|l|}{ Experimental Treatment Variables } \\
\hline Black Picture & 0.496 & 0.5 & 0 & 1 & 982 \\
\hline Reason for Poverty Beyond Control, Willing to Work & 0.241 & 0.4 & 0 & 1 & 982 \\
\hline Reason for Poverty Bad Choices, Not Willing to Work & 0.250 & 0.4 & 0 & 1 & 982 \\
\hline Law-Abiding & 0.520 & 0.5 & 0 & 1 & 982 \\
\hline Shares Own Aid with Others & 0.476 & 0.5 & 0 & 1 & 982 \\
\hline Short-Term Need for Aid & 0.507 & 0.5 & 0 & 1 & 982 \\
\hline Currently Working & 0.516 & 0.5 & 0 & 1 & 982 \\
\hline Religious & 0.530 & 0.5 & 0 & 1 & 982 \\
\hline City is Republican & 0.507 & 0.5 & 0 & 1 & 982 \\
\hline City is Economically Advantaged & 0.506 & 0.5 & 0 & 1 & 982 \\
\hline Salvation Army & 0.494 & 0.5 & 0 & 1 & 982 \\
\hline \# Worthiness Treatments (derived variable, $0-1$ scale) & 0.497 & 0.2 & 0 & 1 & 982 \\
\hline \multicolumn{6}{|l|}{ Perception Variables } \\
\hline$\overline{\text { Perceived Percentage of White Aid Recipients }}$ & 28.0 & 16.1 & 0 & 100 & 965 \\
\hline Perceived Percentage of Black Aid Recipients & 56.6 & 18.4 & 0 & 100 & 965 \\
\hline Perceived Percentage of Aid Recipients from Another Race & 15.5 & 11.7 & 0 & 90 & 965 \\
\hline Perceived Percentage Black - Percent White Aid Recipients & 28.6 & 32.4 & -100 & 100 & 965 \\
\hline Perceived Percentage of Aid Recipients Willing to Work Hard & 53.0 & 24.5 & 0 & 100 & 978 \\
\hline $\begin{array}{l}\text { Perceived Percentage of Aid Recipients Whose Reasons for } \\
\text { Poverty Are Beyond Control }\end{array}$ & 46.8 & 23.3 & 0 & 100 & 977 \\
\hline $\begin{array}{l}\text { Perceived Percentage of Aid Recipients Whose Reasons for } \\
\text { Poverty Are Bad Choices }\end{array}$ & 49.2 & 22.6 & 0 & 100 & 973 \\
\hline Perceived Percentage of Aid Recipients with a Criminal Record & 37.0 & 22.2 & 0 & 100 & 971 \\
\hline $\begin{array}{l}\text { Perceived Percentage of Aid Recipients Willing to Share Own } \\
\text { Aid with Others }\end{array}$ & 36.7 & 26.9 & 0 & 100 & 978 \\
\hline $\begin{array}{l}\text { Perceived Percentage of Aid Recipients on Short-Term } \\
\text { Assistance }\end{array}$ & 39.6 & 24.1 & 0 & 100 & 972 \\
\hline $\begin{array}{l}\text { Perceived Percentage of Aid Recipients Who Attend Religious } \\
\text { Services Weekly }\end{array}$ & 52.4 & 24.3 & 0 & 100 & 969 \\
\hline Perceived Percentage of Aid Recipients Who Voted for Bush & 37.8 & 29.2 & 0 & 100 & 968 \\
\hline $\begin{array}{l}\text { Perceived Average Income of Tuscaloosa Aid Recipients, } \\
\text { Thousands of Dollars per Year }\end{array}$ & 15.4 & 7.8 & 0 & 73 & 977 \\
\hline $\begin{array}{l}\text { Perceived Average Income of All Tuscaloosa Residents, } \\
\text { Thousands of Dollars per Year }\end{array}$ & 26.5 & 11.4 & 0 & 70 & 971 \\
\hline Perceived Percent Black-Percent White City Residents & 11.8 & 35.2 & -100 & 100 & 949 \\
\hline Worthiness Perceptions (derived variable, 0-100 scale) & 50.0 & 16.3 & 3 & 94 & 960 \\
\hline
\end{tabular}




\begin{tabular}{lccccc}
\hline \hline Control Variables & & & & & \\
Age & 48.3 & 16.9 & 18.0 & 92.0 & 982 \\
Age $/ 100$ & 26.2 & 17.0 & 3.24 & 84.6 & 982 \\
White & 0.705 & 0.456 & 0 & 1 & 982 \\
Black & 0.120 & 0.325 & 0 & 1 & 982 \\
Other Race & 0.175 & 0.381 & 0 & 1 & 982 \\
Less than High School & 0.112 & 0.315 & 0 & 1 & 982 \\
High School Degree & 0.332 & 0.471 & 0 & 1 & 982 \\
Some College & 0.287 & 0.453 & 0 & 1 & 982 \\
College Degree or Higher & 0.270 & 0.444 & 0 & 1 & 982 \\
Log Household Income & 10.6 & 0.889 & 7.8 & 12.8 & 982 \\
Dual Income & 0.525 & 0.500 & 0 & 1 & 982 \\
Married & 0.528 & 0.499 & 0 & 1 & 982 \\
Male & 0.488 & 0.500 & 0 & 1 & 982 \\
Single Male & 0.204 & 0.403 & 0 & 1 & 982 \\
Resides in South & 0.367 & 0.482 & 0 & 1 & 982 \\
Working & 0.615 & 0.487 & 0 & 1 & 982 \\
Disabled & 0.064 & 0.245 & 0 & 1 & 982 \\
Retired & 0.174 & 0.379 & 0 & 1 & 982 \\
Fraction Who Gave to Charities in 2005 & 0.810 & 0.393 & 0 & 1 & 982 \\
Log Total Charitable Giving in 2005 & 6.0 & 1.6 & 0.7 & 11.9 & 784 \\
Fraction Who Gave to Charities for the Poor in 2005 & 0.726 & 0.446 & 0 & 1 & 982 \\
Log Total Giving to Charities for the Poor in 2005 & 5.4 & 1.4 & 1.6 & 10.1 & 708 \\
\hline Mens & & & & & \\
\hline
\end{tabular}

Means and standard deviations are weighted to correct for oversampling of black respondents. The variable \# Worthiness Treatments is the average of the following four audio treatments: Reasons for poverty bad choices (reverse coded), reasons for poverty beyond control, law abiding, and willing to share own aid. The variable Worthiness Perceptions is the average of the five corresponding perceptions questions: Reasons for poverty bad choices (reverse coded), reasons for poverty beyond control, willing to work, possessing a criminal record (reverse coded), and willing to share own aid. 
Table 2a: Effects of Treatments on Perceptions

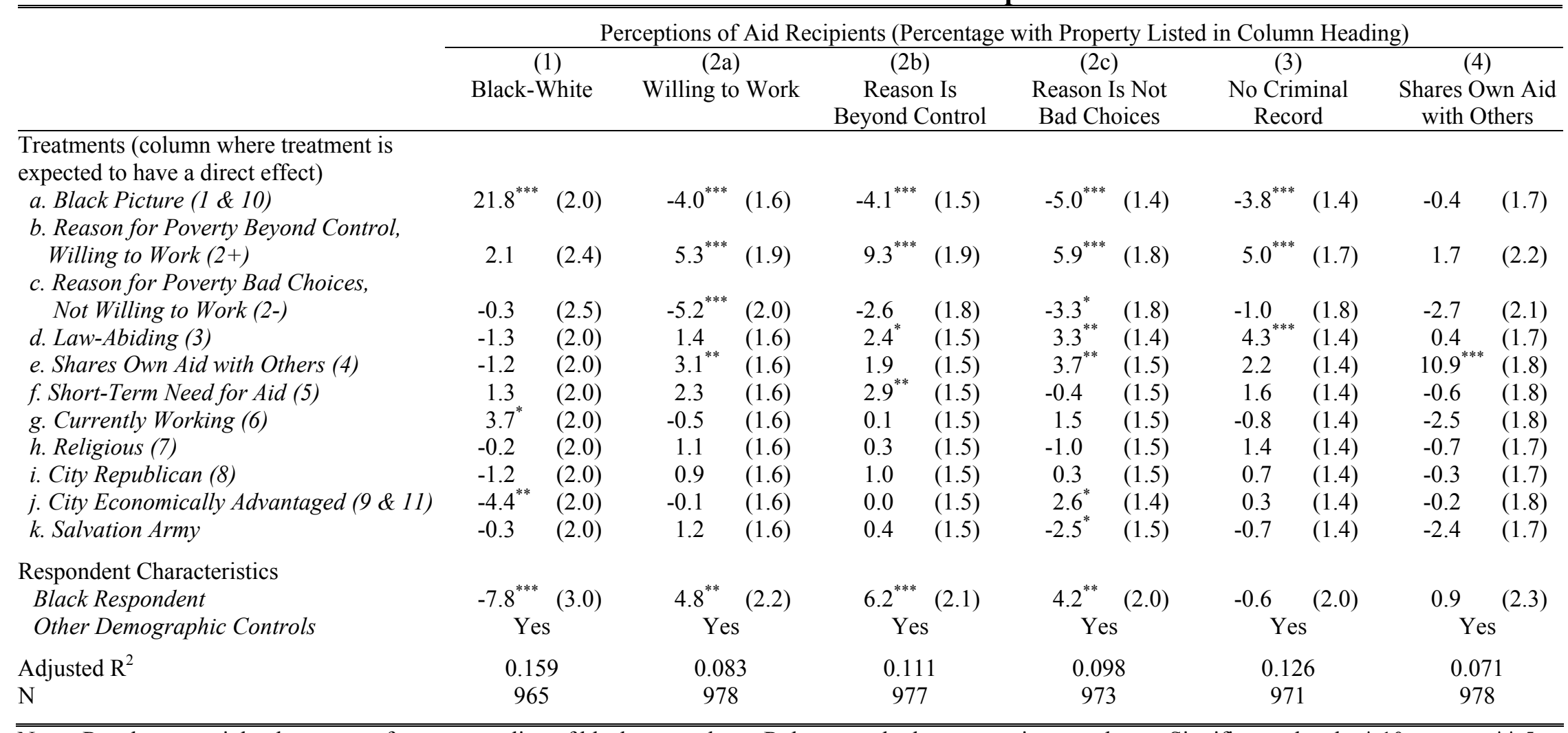

Note: Results are weighted to correct for oversampling of black respondents. Robust standard errors are in parentheses. Significance levels: * 10 percent; $* * 5$ percent; *** 1 percent. Each column is a separate OLS regression with as dependent variable the perception listed in the column heading. See Appendix A for the exact definitions of the experimental treatments. The number in parentheses behind each treatment denote the column number(s) of the perceptions we indeed to be affected by the treatment variable. The demographic controls consist of the variables listed under the heading "control variables" in Table 1 . 
Table 2b: Effects of Treatments on Perceptions

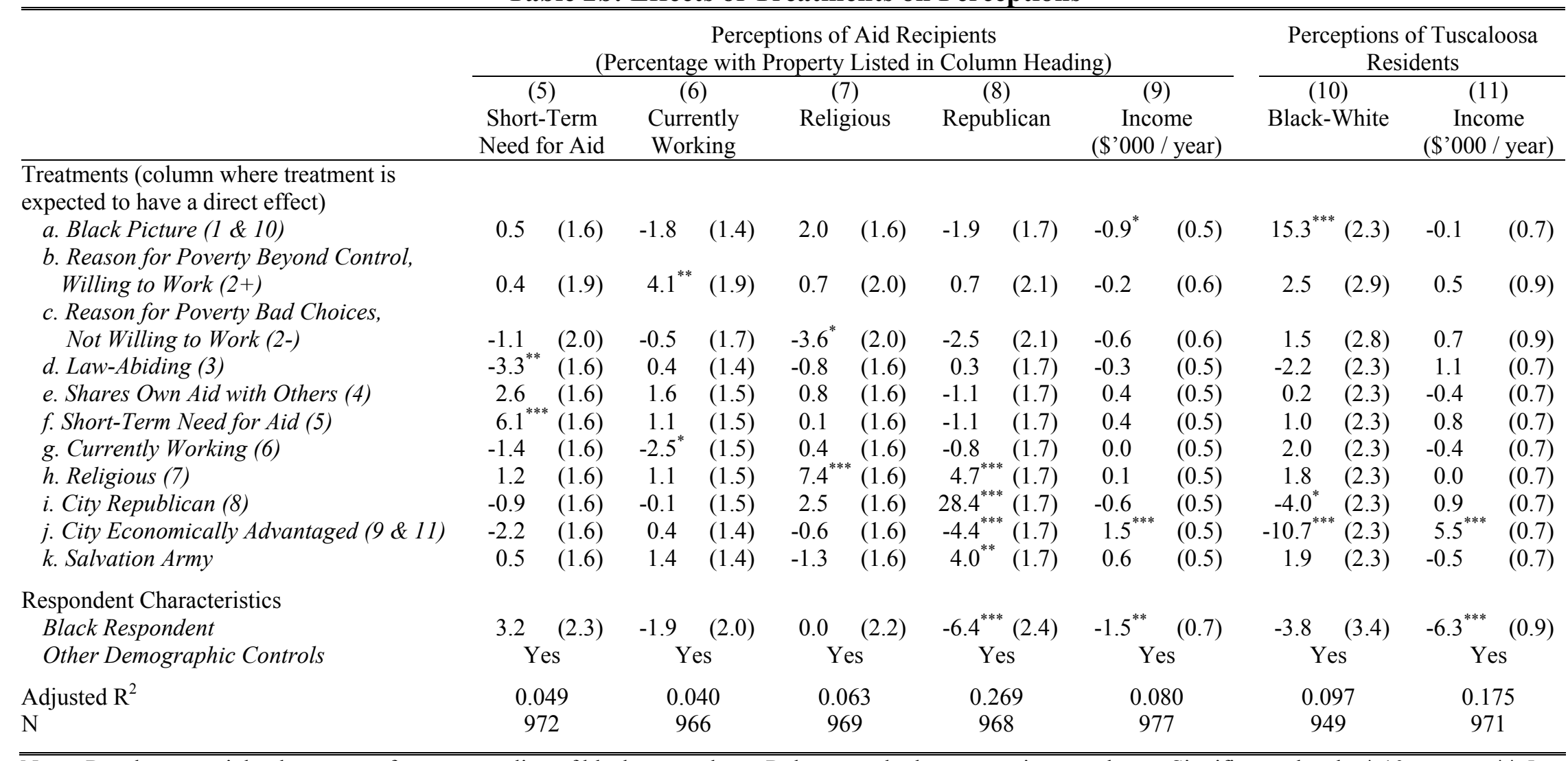

Note: Results are weighted to correct for oversampling of black respondents. Robust standard errors are in parentheses. Significance levels: * 10 percent; $* * 5$ percent; *** 1 percent. See notes to Table $2 \mathrm{a}$. 


\begin{tabular}{|c|c|c|c|c|c|c|c|}
\hline & \multicolumn{2}{|c|}{$(1)$} & \multicolumn{2}{|c|}{$\begin{array}{c}\text { Non-Black } \\
\text { Respondents }\end{array}$} & Black Respondents & All Res1 & hdents \\
\hline \multicolumn{8}{|c|}{ Panel A: Race Perceptions (Dependent variable: perceived percentage black recipients - perceived percentage white recipients) } \\
\hline \multicolumn{8}{|c|}{ Treatments } \\
\hline Black Picture & $21.8^{* * *}$ & $(2.0)$ & $21.1^{* * *}$ & $(2.2)$ & $28.9^{* * *} \quad(5.4)$ & $21.2^{* * *}$ & $(2.2)$ \\
\hline \# Worthiness Treatments & -0.1 & $(3.9)$ & -3.1 & $(4.2)$ & $(10.2)$ & -2.9 & $(4.2)$ \\
\hline Black Picture $\times$ Black Respondent & & & & & & & $(5.4)$ \\
\hline \# Worthiness Treatments $\times$ Black Respondent & & & & & & $21.3^{* *}$ & $(10.3)$ \\
\hline Controls for Other Treatments & \multicolumn{2}{|c|}{ Yes } & \multicolumn{2}{|c|}{ Yes } & Yes & \multicolumn{2}{|c|}{ Yes } \\
\hline Controls for Demographics & \multicolumn{2}{|c|}{ Yes } & \multicolumn{2}{|c|}{ Yes } & Yes & \multicolumn{2}{|c|}{ Yes } \\
\hline $\mathrm{R}^{2}$ & \multicolumn{2}{|c|}{0.157} & \multicolumn{2}{|c|}{0.152} & 0.266 & \multicolumn{2}{|c|}{0.161} \\
\hline $\mathrm{N}$ & \multicolumn{2}{|c|}{965} & \multicolumn{2}{|c|}{764} & 201 & \multicolumn{2}{|c|}{965} \\
\hline
\end{tabular}

Panel B: Worthiness Perceptions (Dependent variable: Average of 5 perceptions questions related to worthiness) Treatments

Black Picture

\# Worthiness Treatments

Black Picture $\times$ Black Respondent

\# Worthiness Treatments $\times$ Black Respondent

Controls for Other Treatments

Controls for Demographics

$\mathrm{R}^{2}$

$\mathrm{N}$

$$
\begin{array}{lllll}
-3.6^{* * *} & (1.0) & -4.2^{* * *} & (1.1) & -0.6 \\
15.2^{* * *} & (2.1) & 16.7^{* * *} & (2.3) & 8.9^{* *}
\end{array}
$$

$(2.3)$

$$
\begin{gathered}
-4.2^{\text {*** }} \\
16.4^{\text {*** }} \\
5.0^{\text {** }} \\
-9.8^{\text {** }}
\end{gathered}
$$

Yes

Yes

0.183

200

$\begin{array}{cccc}\text { Yes } & \text { Yes } & \text { Yes } & \text { Yes } \\ \text { Yes } & \text { Yes } & \text { Yes } & \text { Yes } \\ 0.126 & 0.148 & 0.183 & 0.131 \\ 960 & 760 & 200 & 960\end{array}$

Note: Results are weighted to correct for oversampling of black respondents. Robust standard errors are in parentheses. Significance levels: * 10 percent; ** 5 percent; *** 1 percent. The variable \#Worthiness Treatments is the average of the following four audio treatments: Reasons for poverty bad choices (reverse coded), reasons for poverty beyond control, law abiding, and willing to share own aid. The variable Worthiness Perceptions is the average of the five corresponding perceptions questions: Reasons for poverty bad choices (reverse coded), reasons for poverty beyond control, willing to work, possessing a criminal record (reverse coded), and willing to share own aid. The controls for other treatments consist of the following six treatment variables: short-term need for aid, currently working, religious, city republican, city economically advantaged, and salvation army. The demographic controls consist of the variables listed under the heading "control variables" in Table 1. 
Table 4: Giving During the Experiment

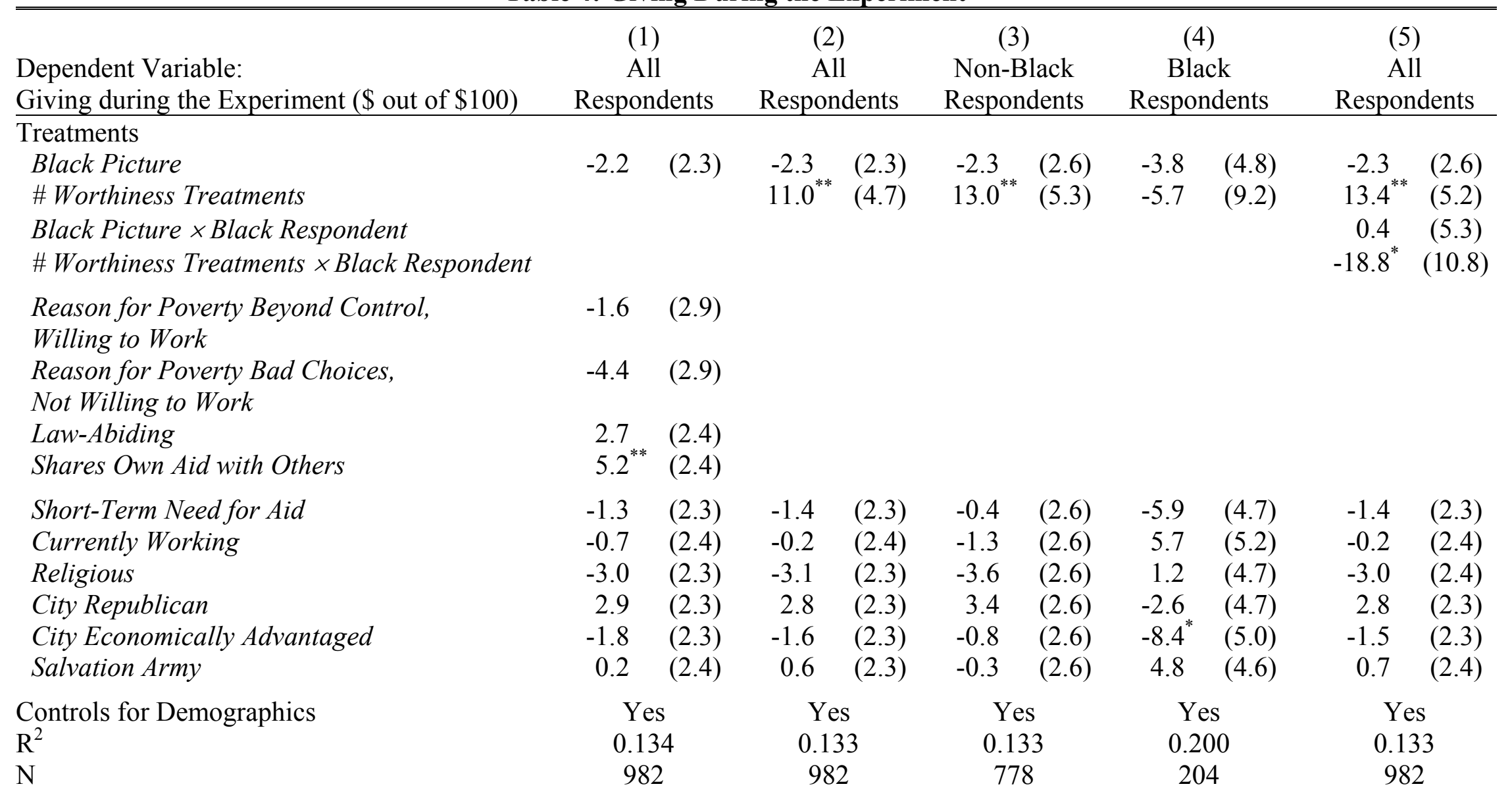

Note: Results are weighted to correct for oversampling of black respondents. Robust standard errors are in parentheses. Significance levels: * 10 percent; ** 5 percent; *** 1 percent. The variable \#Worthiness Treatments is the average of the four audio treatments: Reasons for poverty bad choices (reverse coded), reasons for poverty beyond control, law abiding, and willing to share own aid. The demographic controls consist of the variables listed under the heading "control variables" in Table 1. 
Table 5: Effect of Endogenous versus Exogenous Perceptions on Giving

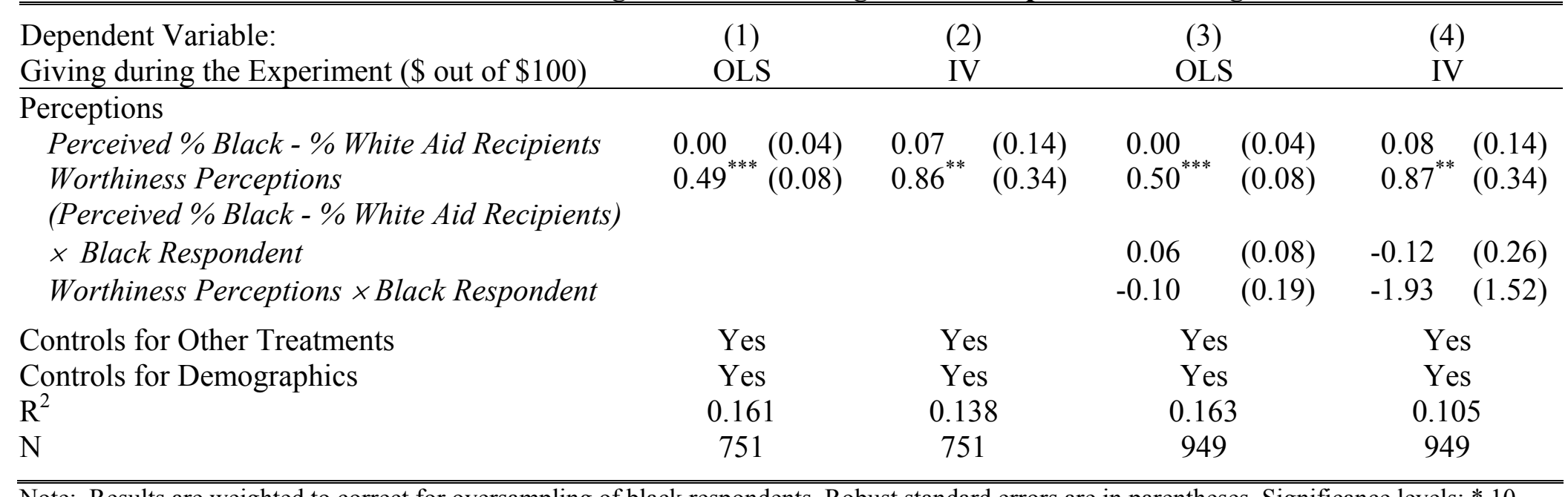

Note: Results are weighted to correct for oversampling of black respondents. Robust standard errors are in parentheses. Significance levels: * 10 percent; ** 5 percent; *** 1 percent. The variable Worthiness Perceptions is the average of the five corresponding perceptions questions: Reasons for poverty bad choices (reverse coded), reasons for poverty beyond control, willing to work, possessing a criminal record (reverse coded), and willing to share own aid. The controls for other treatments consist of the following six treatment variables: short-term need for aid, currently working, religious, city republican, city economically advantaged, and salvation army. The demographic controls consist of the variables listed under the heading "control variables" in Table 1. In the IV regressions, race perceptions and worthiness perceptions are instrumented by the black picture treatment and by the number of worthiness treatments. The sample in columns (1) and (2) is limited to non-black respondents while the sample in columns (3) and (4) consists of the total sample. 
Table 6: Robustness of the Main Result

\begin{tabular}{|c|c|c|c|c|c|c|}
\hline \multirow[b]{2}{*}{ Regression Specification: } & \multicolumn{2}{|c|}{ Black Picture } & \multirow[t]{2}{*}{ \# Worthiness } & \multirow[t]{2}{*}{ Treatments } & \multirow[t]{2}{*}{$\mathrm{R}^{2}$} & \multirow[t]{2}{*}{$\mathrm{N}$} \\
\hline & & & & & & \\
\hline 1. Baseline (Non-Black Respondents Only) & -2.3 & $(2.6)$ & $13.0^{* *}$ & $(5.3)$ & 0.133 & 778 \\
\hline 2. Entire Sample & -2.3 & $(2.3)$ & $11.0^{* *}$ & $(4.7)$ & 0.131 & 982 \\
\hline 3. Whites Only & -3.6 & $(2.9)$ & $12.7^{* *}$ & $(6.0)$ & 0.133 & 623 \\
\hline 4. Ordered Probit & -0.05 & $(0.08)$ & $0.40^{* *}$ & $(0.16)$ & 0.033 & 778 \\
\hline 5. Censored Regression & -3.3 & $(4.8)$ & $25.4^{* * *}$ & $(9.9)$ & 0.021 & 778 \\
\hline 6. No Demographic Controls & -1.9 & $(2.7)$ & $16.1^{* * *}$ & $(5.4)$ & 0.021 & 778 \\
\hline 7. Additional Controls & -0.2 & $(2.6)$ & $12.5^{* *}$ & $(5.3)$ & 0.179 & 761 \\
\hline 8. Hypothetical Giving as Dependent Variable & -0.4 & $(2.2)$ & -4.5 & $(3.3)$ & 0.087 & 777 \\
\hline $\begin{array}{l}\text { 9. Self-Reported Preference for Government Spending } \\
\text { on the Poor in Tuscaloosa as Dependent Variable }\end{array}$ & -0.06 & $(0.10)$ & $0.46^{* *}$ & $(0.20)$ & 0.110 & 773 \\
\hline $\begin{array}{l}\text { 10. Self-Reported Preference for Charity Spending } \\
\text { on the Poor in Tuscaloosa as Dependent Variable }\end{array}$ & 0.06 & $(0.08)$ & 0.28 & $(0.17)$ & 0.101 & 769 \\
\hline
\end{tabular}

Note: Results are weighted to correct for oversampling of black respondents. Robust standard errors are in parentheses. Significance levels: * 10 percent; $* * 5$ percent; *** 1 percent. The baseline regression is the regression of giving during the experiment on treatments and demographics as reported in column 2 of Table 4. All other regressions are identical to the baseline regression except for the change noted in the first column. The additional controls in row 7 consist of: the perceived effectiveness of the charity (measured as fraction of dollars donated to charity reaching needy recipients), the self-reported importance of "helping others in need," and the self-reported importance of "earning a lot of money." 
Table 7: Predictors of Giving During the Experiment vs. Past Charitable Giving

(1)

Giving

During

Experiment

Predicted Charitable Giving

Predicted Giving in Experiment

Age

Age $^{2} / 100$

Non-Hispanic Black

Other Race

Less than High School

Some College

Bachelor's Degree or Higher

Log Household Income

Dual Income

Married

Male

Single Male

Resides in South

Working

Disabled

Retired

$\mathrm{R}^{2}$

$\mathrm{N}$

Mean of Dependent Variable

Std. Dev. of Dependent Variable

Fraction Equal to 0

Fraction Equal to 100

58.6

37.3

0.11

0.35
(2)

Charitable

Giving in 2005
(3)

Giving

During Experiment

(4)

Charitable

Giving in 2005 $0.43^{* * *}(0.06)$

$\begin{array}{cccc}1.2^{* * *} & (0.4) & -0.3 & (0.5) \\ -0.7 & (0.5) & 0.7 & (0.5) \\ -6.9^{* *} & (3.0) & -0.3 & (3.5) \\ -3.6 & (3.3) & 4.9 & (3.6) \\ 5.0 & (4.3) & -4.7 & (4.6) \\ 3.7 & (3.0) & 8.4^{* *} & (3.3) \\ 7.7^{* *} & (3.3) & 15.6^{* * *} & (3.5) \\ 3.5^{* *} & (1.6) & 14.4^{* * *} & (1.8) \\ -2.7 & (2.6) & 0.4 & (2.8) \\ -2.7 & (3.4) & 2.4 & (3.9) \\ 0.8 & (3.4) & -1.9 & (3.5) \\ -3.9 & (4.9) & -4.0 & (5.2) \\ -2.6 & (2.5) & 5.2^{* *} & (2.6) \\ 2.0 & (3.7) & -1.9 & (4.2) \\ -10.3^{*} & (6.1) & -11.2^{*} & (6.1) \\ -0.2 & (5.3) & 0.8 & (5.5)\end{array}$

$\begin{array}{cccc}0.098 & 0.208 & 0.050 & 0.106 \\ 982 & 955 & 982 & 955\end{array}$

55.1

42.0

58.6

55.1

0.16

37.3

42.0

0.11

0.16

0.35

0.35

0.35

Note: Results are weighted to correct for oversampling of black respondents. Robust standard errors are in parentheses. Significance levels: * 10 percent; ** 5 percent; *** 1 percent. The dependent variable in columns (1) and (3) is the number of dollars given during the experiment (out of \$100). The dependent variable in columns (2) and (4) is a transformed measure of total self-reported charitable giving in 2005. To make the scale of the charitable giving variable comparable to the scale of giving during the experiment, we topcode charitable giving at $\$ 500$ so that the fraction of individuals giving the maximum amount is equal. Next, we divide the charitable giving variable by 5 , so that both dependent variables are measured on a $0-100$ scale. The variable Predicted Charitable Giving is the amount predicted by the regression in column (2). The variable Predicted Giving in Experiment is the amount predicted by the regression in column (1). 
Appendix Table 1: Representativeness of the Sample

\begin{tabular}{|c|c|c|c|c|c|c|}
\hline & \multicolumn{2}{|c|}{ Knowledge Networks } & \multicolumn{2}{|c|}{$\begin{array}{c}\text { Current Population } \\
\text { Survey }\end{array}$} & \multirow{2}{*}{$\begin{array}{c}\text { Mean } \\
\text { Difference } \\
\text { (KN-CPS) }\end{array}$} & \multirow[b]{2}{*}{ p-value } \\
\hline & Mean & SD & Mean & SD & & \\
\hline$\overline{\text { Age }}$ & 48.3 & 16.9 & 45.7 & 17.4 & 2.6 & 0.00 \\
\hline $\operatorname{Age}^{2} / 100$ & 26.2 & 17.0 & 23.9 & 17.3 & 2.3 & 0.00 \\
\hline \multicolumn{7}{|l|}{ Education } \\
\hline Less than High School & 0.112 & 0.315 & 0.154 & 0.361 & -0.042 & 0.00 \\
\hline High School & 0.332 & 0.471 & 0.317 & 0.465 & 0.015 & 0.34 \\
\hline Some College & 0.287 & 0.453 & 0.269 & 0.439 & 0.018 & 0.23 \\
\hline Bachelor's Degree or Higher & 0.270 & 0.444 & 0.260 & 0.444 & 0.010 & 0.51 \\
\hline Non- Hispanic Black & 0.120 & 0.325 & 0.112 & 0.316 & 0.008 & 0.37 \\
\hline Non-Hispanic White & 0.705 & 0.456 & 0.695 & 0.460 & 0.009 & 0.52 \\
\hline Other Race / Ethnic Group & 0.175 & 0.381 & 0.192 & 0.394 & -0.017 & 0.19 \\
\hline Male & 0.488 & 0.500 & 0.483 & 0.500 & 0.004 & 0.78 \\
\hline Log Household Size & 0.779 & 0.531 & 0.947 & 0.528 & -0.168 & 0.00 \\
\hline Log Household Income & 10.599 & 0.889 & 10.74 & 0.984 & -0.141 & 0.00 \\
\hline \multicolumn{7}{|l|}{ Annual Household Income } \\
\hline Less than $\$ 20,000$ & 0.178 & 0.383 & 0.168 & 0.374 & 0.010 & 0.42 \\
\hline$\$ 20,000$ to $\$ 40,000$ & 0.275 & 0.447 & 0.237 & 0.425 & 0.038 & 0.01 \\
\hline$\$ 40,000$ to $\$ 75,000$ & 0.322 & 0.468 & 0.297 & 0.457 & 0.026 & 0.10 \\
\hline$\$ 75,000$ to $\$ 100,000$ & 0.119 & 0.324 & 0.124 & 0.330 & -0.005 & 0.63 \\
\hline More than $\$ 100,000$ & 0.106 & 0.308 & 0.174 & 0.379 & -0.068 & 0.00 \\
\hline Has Child under 18 in Household & 0.254 & 0.435 & 0.299 & 0.458 & -0.045 & 0.00 \\
\hline \multicolumn{7}{|l|}{ Marital Status } \\
\hline Married with Children & 0.164 & 0.370 & 0.243 & 0.429 & -0.079 & 0.00 \\
\hline Married without Children & 0.364 & 0.481 & 0.321 & 0.467 & 0.042 & 0.01 \\
\hline Single without Children & 0.196 & 0.397 & 0.056 & 0.416 & 0.139 & 0.00 \\
\hline $\begin{array}{l}\text { Divorced, Separated, or Widowed; } \\
\text { without Children } \\
\text { Single, Divorced, Separated, or }\end{array}$ & 0.187 & 0.390 & 0.222 & 0.364 & -0.036 & 0.01 \\
\hline Widowed; with Children & 0.090 & 0.286 & 0.157 & 0.231 & -0.067 & 0.00 \\
\hline \multicolumn{7}{|l|}{ Region } \\
\hline Northeast & 0.178 & 0.383 & 0.187 & 0.390 & -0.009 & 0.49 \\
\hline Midwest & 0.231 & 0.422 & 0.223 & 0.417 & 0.007 & 0.60 \\
\hline South & 0.367 & 0.482 & 0.362 & 0.481 & 0.006 & 0.72 \\
\hline West & 0.223 & 0.417 & 0.228 & 0.419 & -0.004 & 0.76 \\
\hline Live in Metropolitan Area & 0.848 & 0.360 & 0.834 & 0.372 & 0.014 & 0.25 \\
\hline \multicolumn{7}{|l|}{ Work Status } \\
\hline Retired & 0.174 & 0.379 & 0.163 & 0.369 & 0.011 & 0.38 \\
\hline Disabled & 0.064 & 0.245 & 0.049 & 0.216 & 0.015 & 0.06 \\
\hline \multicolumn{7}{|l|}{ Unemployed, Laid Off, or Looking for } \\
\hline Work & 0.034 & 0.180 & 0.030 & 0.170 & 0.004 & 0.51 \\
\hline Not Working for Some Other Reason & 0.114 & 0.318 & 0.110 & 0.313 & 0.003 & 0.76 \\
\hline
\end{tabular}

The CPS data was extracted from the June 2006 Current Population Survey; the sample is limited to individuals 18 and older. The number of observations in the Knowledge Networks data is 982. The Knowledge Networks means and standard deviations are weighted to correct for oversampling of black respondents. The number of observations for CPS data is 101,073, except for the income variables, which have 83,591 observations. 